\title{
Law Firm Selection and the Value of Transactional Lawyering
}

\author{
Elisabeth de Fontenay*
}

Following the contraction in demand for law firms' services during the Great Recession, "Big Law" was widely diagnosed as suffering from several maladies that would spell its ultimate demise, including excessive fees, excessive size, increased competition from in-house counsel, the commoditization of legal work, and the decline in demand for "relationship firms." While each of these market pressures is only too real for certain segments of the law-firm population, their threat to the most elite U.S. law firms has been largely misunderstood. Even as many firms reduce their fees and contract in size, we should expect certain firms to continue to charge more and grow bigger. The current prescriptions for fixing Big Law fail to recognize that the top-tier firms within the group serve a unique market function.

Focusing on a particular type of legal work-major corporate transactions-this Article proposes a novel theory of the value created by elite law firms: their private information about "market" deal terms, acquired through repeated exposure to the same types of transactions, provides clients with a significant bargaining advantage in deal negotiations. By aggregating expertise in the ever-changing and ever-increasing set of deal terms for certain transactions, law firms help their clients price such terms more accurately and thereby maximize their surplus from the deal. This pricing function-traditionally thought to be limited to investment banks-is one that cannot be replicated or subsumed by in-house counsel, other service providers, or commoditized contracts.

\footnotetext{
* Associate Professor, Duke University School of Law (defontenay@law.duke.edu). For comments and suggestions, thanks are due to Jennifer Arlen, John Coyle, Catherine de Fontenay, Deborah DeMott, Mitu Gulati, Kim Krawiec, Rebecca Morrow, Barak Richman, Steven Schwarcz, Andrew Verstein, and participants in workshops and seminars at Duke University School of Law, Harvard Law School, NYU School of Law, Stanford Law School, and Yale Law School. Mitchell Brunson, Talley Wood, and Dyna Zekaoui provided excellent research assistance. All errors are mine.
} 


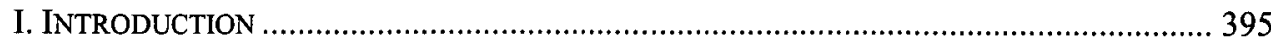

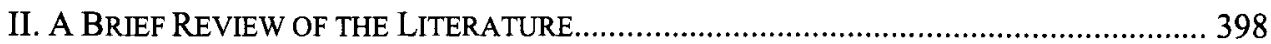

A. The Value of Transactional Lawyers: Three Paradigms ............................... 398

B. The Value of Transactional Lawyers: What's Missing ................................. 402

III. A NEW THEORY OF LAW FIRM VALUE: AGGREGATING MARKET INFORMATION ...... 405

A. The Need for Market Information ................................................................ 406

1. Novel Deal Terms: The Ever-Expanding Bargaining Frontier .................. 407

2. Market Shifts in Non-Price Terms......................................................... 408

B. Market Information About Deal Terms Is Often Private ................................ 411

C. High-Volume Law Firms Have the Best Access to the Full Package of Deal Terms.

IV. MARKET INFORMATION IN PRACTICE: A CASE STUDY .......................................... 413

A. Leveraged Loans: Background .................................................................. 413

B. Leveraged Loan Pricing Using Market Information: Application ................... 415

1. Case 1: The Informed Law Firm's Intervention Is Value-Increasing by Informing the Counterparties of a Mutually Beneficial Term ................... 416

2. Case 2: The Informed Law Firm's Intervention is Value-Increasing by Assisting with the Pricing of a Term ..................................................... 417

3. Case 3: Informed Law Firm's Intervention is Merely Value-Shifting......... 418

4. Case 4: Informed Law Firm's Intervention is Value-Decreasing for

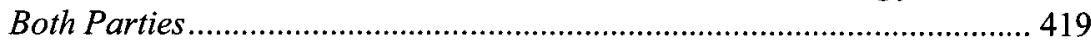

V. IS THIS REALly VALUE? SOME ClaRIFICATIONS AND IMPLICATIONS .......................4 420

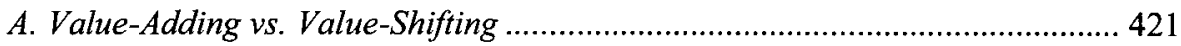

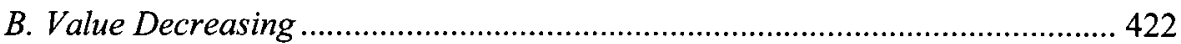

C. Conditions Under Which Market Knowledge Should Provide Value to Clients

D. Do Law Firms Really "Price” Transaction Terms? ...................................... 425

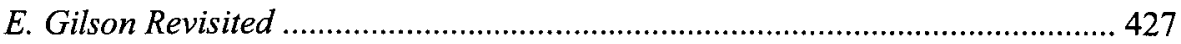

F. The "Value" of Confidentiality .................................................................. 428

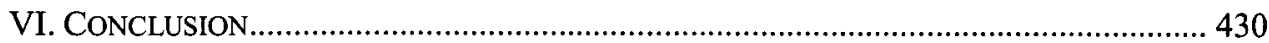




\section{INTRODUCTION}

In the age of increasingly sophisticated in-house counsel, what exactly are the benefits that law firms provide to their clients? Among law firms, what does the relative ranking or prestige of a law firm actually reflect? Although these questions are of enormous and urgent practical interest, the scholarship addressing them remains surprisingly limited. We can begin our inquiry with a puzzle. Discussions of the legal profession today devote much attention to the need for "Big Law" to provide more cost-effective services to their clients. ${ }^{1}$ The still-recent financial crisis and continuing sluggish economic growth in the United States have only rendered these calls for reform more urgent. Because law firms fail to provide sufficient value in return for their fees, the argument goes, demand for their services has slackened, resulting in painful layoffs for experienced lawyers and a dismal job market for recent law school graduates. ${ }^{2}$

Yet this dire picture ignores a surprising-and, perhaps, dismaying-reality: it is precisely those law firms that charged the highest fees before the downturn for whom demand continues to be greatest and who are best weathering the crisis in the legal profession. ${ }^{3}$ While many lower-ranked law firms continue to struggle, the highest-ranked firms present a picture of financial health and perennially overworked lawyers. ${ }^{4}$ There is a widening chasm between the most elite corporate law firms and the rest of the pack in terms of transaction volume, billing rates, lawyer compensation, and hiring. 5

1. See Larry E. Ribstein, The Death of Big Law, 2010 WIS. L. REV. 749, 749 (2010) (discussing "the forces driving the downsizing of Big Law" and suggesting alternative viable business models for legal services); RICHARD SuSSKIND, THE END OF LAWYERS? RETHINKING THE NATURE OF LEGAL SERVICES 1-3 (2008) (predicting a diminished role for lawyers as a result of cost pressures and technological innovation); see also William D. Henderson, From Big Law to Lean Law, 38 INT'L REV. L. \& ECON. 5, 14 (2013) (agreeing that "the Big Law model is, in fact, dead" and predicting a new era of "Lean Law"); Antone Johnson, Why Are Lawyers So Expensive Even With The Excess Of Supply Of Lawyers?, ForBES (Mar. 6, 2012, 2:55 PM), http://www.forbes .com/sites/quora/2012/03/06/why-are-lawyers-so-expensive-even-with-the-excess-supply-of-lawyers/ (arguing that large law firms should decrease their billing rates in response to decreased demand for lawyers).

2. See Elizabeth Olson, Corporations Drive Drop in Law Firms' Use of Starting Lawyers, Study Finds, N.Y. TIMES (Oct. 10, 2014, 12:25 PM), http://dealbook.nytimes.com/2014/10/10/corporations-drive-drop-in-lawfirms-use-of-starting-lawyers-study-finds/? ${ }_{-}=0$ (describing companies' increasing reluctance to pay for the services of untrained associates at law firms).

3. See Bemard Burk \& David McGowan, Big but Brittle: Economic Perspectives on the Future of the Law Firm in the New Economy, 2011 COLUM. BUS. L. REV. 1, 6 (2011) (disagreeing with Ribstein's prediction of the "death of Big Law" and arguing instead that the "recession['s] . . economic forces ... do not threaten the viability of the large law firm as such"); Daniel Currell \& M. Todd Henderson, Can Lawyers Stay in the Driver's Seat?, 38 NT'L REV. L. \& ECON. 17, 19 (2014) (critiquing Ribstein and arguing that "law firms are doing very, very well"); see also Liz Hoffman \& Jennifer Smith, Elite Law Firms Reign as Megadeals Blossom, WALL STREET J., July 14, 2014, at B1 (discussing the success of the top five firms due to Megadeals).

4. See Aric Press, Am Law 100 Analysis: The Super Rich Get Richer, AM. LAw. (Apr. 28, 2014), http://www.americanlawyer.com/id=1202651706887/Am-Law-100-Analysis-The-Super-Rich-Get-Richer?slreturn=20140915093251 (surveying the top 100 U.S. law firms by revenue and noting that, unlike their counterparts, the "Super Rich firms - the 20 with [profits per partner] of at least $\$ 2$ million and [revenue per lawyer] of at least $\$ 1$ million"-outperformed the financial averages by four or five percentage points ....").

5. See Citi Private Bank \& Hildebrandt Consultang LlC, 2015 Client AdVISORY 3 (2015), https://www.privatebank.citibank.com/pdf/CitiHildebrandt2015ClientAdvisory.pdf (finding the "continued growing separation in the market between the most profitable [law] firms and the rest" with respect to transactional work); see also Hoffman \& Smith, supra note 3 (noting the "growing gulf in the broader legal industry as a handful of the most prominent--and profitable--law firms, pull ahead of the pack"). 
What accounts for this widening inequality among law firms? The most plausible explanation is that the top-ranked firms provide clients with one or more valuable benefits that lower-ranked firms cannot. Focusing on a particular type of legal practice-major corporate transactions - this Article proposes that law firms that repeatedly engage in the same type of high-stakes transactions acquire private information about the range of plausible deal terms and their current market prices that other players cannot replicate. ${ }^{6}$ This expertise in the ever-changing, ever-expanding set of "market" deal terms provides clients with a valuable bargaining advantage in deal negotiations. Law firms that are repeat players with respect to particular types of corporate transactions use their market knowledge to procure better economic deals for their clients. Though this hypothesis by no means rules out other ways in which elite firms add value, it would account for the seemingly self-reinforcing advantage of high-volume firms. The failure to recognize law firms' informational role in transactions and its effect on bargaining outcomes reflects a widespread misunderstanding, akin to equating the role of an investment bank to that of a commercial bank.

The argument is as follows. Although many corporate transactions become standardized and even commoditized over time, ${ }^{7}$ others involve increasingly complex or rapidly changing terms for a sustained period of time. The latter type consists of heavily negotiated, bilateral transactions, characterized by variation in the market price of deal terms, the constant development of new terms, or both. ${ }^{8}$ Such transactions stray from the perfect-market ideal of transparent, uniform pricing. Rather, information about individual deal terms and their pricing remains largely private (and therefore scarce). For a given deal, the final set of negotiated terms will be determined by a combination of market forces and bargaining under incomplete information and will thus be heavily affected by the parties' respective information in the bargaining stages.

To maximize their gains from this type of transaction, the parties must know the benefit or cost of each deal term to each party, as well as how to trade off terms against one another under current market conditions. A necessary-though by no means sufficient-condition to acquiring that information is real-time access to the terms of a significant volume of recent comparable transactions. Such market information about deal terms assists parties with three tasks that are crucial for transactional bargaining: (1) learning of any new terms that provide value-increasing opportunities; (2) determining their expected payoffs from each deal term; and (3) determining the value of their outside option. ${ }^{9}$ Where do parties obtain this expert information? The most obvious source, I argue, is law firms that routinely engage in the type of transaction at issue. By definition, private

6. Infra Part III.

7. See SUSSKIND, supra note 1, at 28-33 (describing the evolution of legal services from bespoke to fully commoditized).

8. Transactions falling within each of these three categories currently include mergers and acquisitions, private investment fund agreements, and leveraged debt financings, respectively, though this need not continue to be the case.

9. A party's "outside option" is the payoff that it would obtain if it had to break off negotiations for the current transaction and return to the market for an alternative. In the negotiations literature, the "outside option" is referred to the "best alternative to a negotiated agreement" (BATNA). The outside option is a key determinant of a negotiator's results. See Roger FISHER \& William URY, GeTting to Yes: Negotiating AgREEMENT WITHOUT GIVING IN 99-107 (Bruce Patton ed., 3d ed. 1981) (providing step-by-step instruction and advice to finding a mutually agreeable end to negotiations). 
transactions - or public transactions for which some terms remain private-have opaque term pricing. Law firms retain a near monopoly over the complete deal terms for such transactions because they are repeat players across a range of different clients. Unlike other transaction participants, they negotiate and draft the full panoply of transaction terms, from signing to closing and potentially beyond (through disputes, renegotiation, and resolution). While third-party data providers have made substantial inroads in aggregating and comparing corporate deal terms, ${ }^{10}$ they are largely confined to reviewing publicly available documents ex post.

The hypothesis that law firms create value through market knowledge is supported by the changing nature of the transactional work performed at elite law firms. Associates at such firms may now devote much, if not most, of their time to aggregating and comparing their firm's "market precedent" in preparation for a client's potential transaction. ${ }^{11}$ Unsurprisingly, firms' practices in this regard should tend to become more sophisticated and routinized as the amount of information to be compiled grows and knowledgemanagement technology improves.

This reconceiving of the role played by law firms in corporate transactions challenges fundamental and longstanding assumptions about the law firm-client relationship. ${ }^{12}$ The rules of professional responsibility for lawyers zealously endorse the confidentiality of client information. Yet, in practice, clients are paying for law firms' ability to pool information across clients and to make use of that information in transaction negotiations. A Fortune 500 company engages a top-tier law firm for its proposed merger precisely because the firm will know-and use-the terms obtained by similar companies in recent mergers. Such clients do not seek bespoke, professional service based on a long-term, confidential relationship. ${ }^{13}$ They are, in effect, merely purchasing information from law firms, which in turn are merely engaged in the increasingly ubiquitous practice of knowledge management. ${ }^{14}$ Yet this form of knowledge management should continue to generate above-market rents for elite firms, which have better-and sometimes exclusive-access to the underlying information relative to other market participants.

Finally, this hypothesis of law firm value calls for some optimism about the future of law firms with elite transactional practices-defined here as those with a significant market share of the very largest transactions by dollar value-while sounding a cautionary note

10. Companies such as Xtract Research, Practical Law, and The Deal provide searchable databases of key terms from corporate transactions.

11. See, e.g., Wilson Sonsini Goodrich \& Rosati, Professional Development \& Knowledge Management Programs Institution (2013), https:/www.wsgr.com/PDFs/professional-development-brochure.pdf (describing the firm's searchable internal database of precedent transactions). In practice, this knowledge management exercise may be implemented by law firms in various ways, from using sophisticated database software to track all of the terms of precedential transactions, or tabulating recent deal terms manually, to the more informal and traditional practice of simply gathering and reviewing recent comparable transaction documents before beginning a negotiation.

12. See infra Section V.F (discussing the value of confidentiality and its effect on clients' choice of law firm).

13. See generally Ronald J. Gilson, The Devolution of the Legal Profession: A Demand Side Perspective, 49 MD. L. REV. 869 (1990) (describing the decline in relationship lawyering).

14. Cf. Christopher D. MCKenNa, THe World's NewEST PROFESSION: MaNAGEMENT CONSULTING $\mathbb{N}$ THE TWENTIETH CENTURY 8-25 (2006) (arguing that management consultants are richly compensated simply for selling access to their database of information gathered from numerous clients). 
for in-house counsel. Law firms will always retain their private market knowledge as a crucial advantage over their in-house counterparts, however experienced and sophisticated the latter may be. For the most part, in-house lawyers are privy only to their employer's own transactions, in contrast to law firms' real-time access to a wide range of precedential transactions. The trumpeting of in-house counsel as a solution to spiraling legal costs ${ }^{15}$ should thus be more muted: for the most lucrative areas of transactional practice, clients will continue to seek the most prestigious law firms. ${ }^{16}$

We can end our inquiry with another puzzle - that of the ever-expanding law firm. Various theories have been advanced to explain the increasing prevalence of the mega-law firm. ${ }^{17}$ While each of these provides a partial explanation, under this Article's thesis larger firms also reflect the self-perpetuating informational advantage derived from greater deal volume. ${ }^{18}$

The Article proceeds as follows: Part II reviews the existing literature on the value, if any, provided by transactional lawyers. In Part III, puzzles left unsolved by the existing literature yield a new theory of law firm value in the transactional context, focusing on elite firms' market knowledge. Part IV illustrates the market-knowledge hypothesis with a case study of leveraged financing transactions. Part V clarifies the circumstances in which law firms' use of market knowledge should be value-increasing, value-shifting, or valuedecreasing, and discusses certain key implications.

\section{A BRIEF REVIEW OF THE LITERATURE}

\section{A. The Value of Transactional Lawyers: Three Paradigms}

As with other professional services, the costs of legal services have been increasing faster than inflation in recent decades. For clients, then, the question of what they are getting in return for their legal fees is a pressing one. Yet clients' ability to assess their

15. See, e.g., Abram Chayes \& Antonia H. Chayes, Corporate Counsel and the Elite Law Firm, 37 STAN. L. REV. 277, 277-80 (1985) (noting the increased prominence of in-house counsel and predicting a corresponding contraction in the roles played by outside law firms).

16. See generally Steven L. Schwarcz, To Make or to Buy: In-House Lawyering and Value Creation, $33 \mathrm{~J}$. CORP. L. 497 (2008) (discussing in detail the considerations involved in choosing between in-house and outside counsel).

17. See Georgetown Law Center for the Study of the Legal Profession, 2014 Report on the STATE OF THE LEGAL MARKET 1, 9 (2014), https://peermonitor.thomsonreuters.com/wp-content/uploads/2014/01 12014_PM_GT_Report.pdf (documenting the continued trend toward larger firms and listing the most common explanations for the phenomenon as "(i) the desire to achieve 'economies of scale,' (ii) the necessity of creating an 'ever expanding pie' to provide opportunities for younger lawyers ... (iii) the need to diversify to protect a firm against cyclical downturns in specific practices, and (iv) the requirements for a larger market footprint to better serve the needs of clients").

18. This should not be taken to suggest that law firms should seek to expand indefinitely. Other efficiencyrelated concerns (such as the notorious difficulties and duplication involved in managing large organizations) might suggest a maximum desirable size for a given firm. Further, certain firms may be able to increase their transaction volume without necessarily increasing the number of lawyers, for instance by increasingly delegating or outsourcing the more routine aspects of transactional work. Among elite law firms, New York-based Wachtell, Lipton, Rosen \& Katz is well known for adopting this model. See K. William Gibson, Outsourcing Legal Services Abroad, 34 L. PRAC. MAG. 47 (2008), http://www.americanbar.org/publications/law_practice_home/law_practic e_archive/lpm_magazine_articles_v34_is5_pg47.html (discussing law firms' practice of outsourcing legal work). 
outside counsel's performance is limited. ${ }^{19}$ The law firm-client relationship poses the classic agency problem: the principal (here, the client) lacks complete information about the agent's (the law firm's) performance of its duties, which allows the agent to act to some degree in its own interests at the expense of the principal's. ${ }^{20}$ The existing literature's focus on this agency problem puts the cart before the horse, however. Before examining how well clients are able to monitor and assess their law firms, we should clarify just what it is that, in the absence of agency costs, law firms would ideally accomplish. Simply put, what does it mean to be a good lawyer? When a law firm is hired by a corporate client, what is the value that it is meant to provide? These questions are paramount. The agency-cost analysis only identifies the ways in which law firms and lawyers may knowingly depart from their clients' interests, such as by shirking and over-billing. Yet one could easily imagine a law firm working diligently for its client and billing conservatively, while still failing to deliver any value. The agency costs involved in the law firm-client relationship are far from the only, or even the most important, considerations in law firm selection.

Though the agency-cost path is better trodden, scholars have made significant progress in identifying the sources of value provided by lawyers. The value question is particularly intriguing in the context of transactional lawyering, which is this Article's focus. Major corporate transactions, ${ }^{21}$ such as mergers and acquisitions and financings, require large teams of lawyers. ${ }^{22}$ But what is it that such lawyers do, and why? Unlike the litigation context, in which the lawyer's role qua lawyer is clear in the public imagination, transactional lawyers are often accused of -or congratulated for-not being lawyers at all. Referred to even in firms' own marketing materials as advisers, deal-makers, or business planners, ${ }^{23}$ these mysterious figures cost clients a pretty penny in any case.

In his seminal 1984 article, Ronald Gilson dispelled some of the mystery by identifying transactional lawyers as "transaction cost engineers." $24 \mathrm{He}$ began from the premise that, in contrast to the standard perfect-market assumptions, corporate transactions involve substantial transaction costs. ${ }^{25}$ Much of these costs stem from the parties'

19. See John C. Coates IV, Explaining Variation in Takeover Defenses: Blame the Lawyers, 89 CAL. L. REV. 1301, 1310 (2001) (noting that, as with all agency relationships, "principals (clients) have little information about what their agents are doing").

20. See id. at 1309-10 (describing the law firm/client agency relationship); SUSSKIND, supra note 1, at 14849 (describing the divergent incentives of law firms and their clients).

21. For purposes of this Article, "major corporate transactions" are defined loosely as corporate transactions that represent all or a significant portion of the enterprise value of at least one party or that involve significant changes in the capital structure, assets, or organization of the corporation.

22. See Ribstein, supra note 1, at 763 (noting large financial transactions require teams of lawyers spanning multiple departments and areas of expertise).

23. See SUSSKIND, supra note 1, at 5 (noting the phenomenon of "lawyers denying that they are lawyers").

24. Ronald J. Gilson, Value Creation by Business Lawyers: Legal Skills and Asset Pricing, 94 YALE L.J. 239, 255 (1984) (emphasis removed); see also Lisa Bemstein, The Silicon Valley Lawyer as Transaction Costs Engineer?, 74 OR. L. REV. 239, 250-51 (1995) (describing the various means--both contractual and relationalby which Silicon Valley lawyers may reduce transaction costs in venture capital financings); Peter J. Gardner, $A$ Role for the Business Attorney in the Twenty-First Century: Adding Value to the Client's Enterprise in the Knowledge Economy, 7 MARQ. INTELL. PROP. L. REV. 17, 36 (2003) (discussing the role of business lawyers in the legal professional); Ronald J. Gilson \& Robert H. Mnookin, Foreword: Business Lawyers and Value Creation for Clients, 74 OR. L. REV. 1, 2 (1995).

25. See Gilson, supra note 24 , at 253 (noting "pervasive" transaction costs in real-world transactions). 
asymmetric information as to the true value of the asset to be transferred between them. ${ }^{26}$ In the sale of a company, for example, the seller is always better informed about the company's value than the buyer, making it difficult to reach a deal and to price it accurately. Gilson hypothesized that good transactional lawyers minimize such information costs for the parties, for example by allocating each risk involved in the transaction to the party best able to bear it. ${ }^{27}$ For the sale of a company, for example, lawyers craft provisions such as seller representations and warranties, perhaps backed up by the seller's obligation to indemnify the buyer in the event of a breach. Such provisions provide more information and greater assurances to the buyer as to the value of the company and therefore increase the likelihood that a deal will be reached and correctly priced. Thus, by minimizing transaction costs, transactional lawyers can increase the parties' joint surplus (value) from the transaction, making both sides better off. Among other merits, Gilson's theory is comforting to both lawyers and clients: it entails that, in hiring transactional lawyers, clients are better off relative to a hypothetical lawyer-free deal. ${ }^{28}$

A competing paradigm to the transactional law firm as "transaction cost engineer" is that of the law firm as "reputational intermediary" or "gatekeeper" in corporate transactions. ${ }^{29}$ In this view, law firms perform the service of renting their good reputations to clients, thereby enabling them to complete a desired transaction or to obtain better terms for the transaction. Take, for example, a start-up company seeking to secure new funding through an initial public offering (IPO). The dearth of reliable information about the startup relative to, say, an established public company presents a major obstacle to attracting investors. If the company or its underwriters hires a highly reputable law firm for the IPO,

26. Id. at 269.

27. Id. at 259 n. 50 .

28. Interestingly, the debate over whether transactional lawyers add or subtract value remains unresolved. Gilson's hypothesis is, by his own admission, theory-based, and to the author's knowledge has not been directly tested empirically. Gilson argues that transactional lawyers must add value (rather than simply redistribute it between the parties); otherwise, the parties would jointly agree not to use lawyers. See id. at $245-46$ (stating clients would not hire lawyers for transactional work if value were not added). Jeffrey Lipshaw argues that this assumption of value-creation may be unwarranted. See Jeffrey M. Lipshaw, Beetles, Frogs, and Lawyers: The Scientific Demarcation Problem in the Gilson Theory of Value Creation, 46 WILlameTTE L. REV. 139, 142 (2009) (noting that, if anecdotal evidence is to be believed, many clients feel that their lawyers were a negativevalue proposition). For specific types of transactions, some evidence points to elite law firms having a positive impact on transactional value. See, e.g., C.N.V. Krishnan \& Ronald W. Masulis, Law Firm Expertise and Merger and Acquisition Outcomes, 56 J.L. \& ECON. 189, 192 (2013) (finding that top-tier law firms are associated with better outcomes for clients in mergers and acquisitions but declining to specify the precise mechanism by which this is achieved).

29. See Karl S. Okamoto, Reputation and the Value of Lawyers, 74 OR. L. REV. 15, 18-19 (1995) (arguing that elite law firms act as reputational intermediaries for their clients, but noting the decline in this function over time); Ronald J. Gilson \& Robert H. Mnookin, Disputing Through Agents: Cooperation and Conflict Between Lawyers in Litigation, 94 COLUM. L. REV. 509, 512-13 (1994) (discussing lawyers' reputational role in litigation); Gilson, supra note 24, at 290-93 (discussing lawyer's role in verifying information in acquisitions); Reinier $\mathrm{H}$. Kraakman, Gatekeepers: The Anatomy of a Third-Party Enforcement Strategy, 2 J.L. ECON. \& ORG. 53, 61 n.20 (1986) (stating that banking law firms are reputational intermediaries in the market); Larry E. Ribstein, Ethical Rules, Agency Costs, and Law Firm Structure, 84 VA. L. REv. 1707, 1739-40 (1998) (arguing elite firms perform societal functions such as policing corporate clients' behavior). The concept of a "reputational intermediary" originated in a seminal article by Ronald Gilson and Reinier Kraakman and is not limited to lawyers. See Ronald J. Gilson \& Reinier H. Kraakman, The Mechanisms of Market Efficiency, 70 VA. L. REV. 549, 621 (1984) (describing the investment banker as a reputational intermediary). 
however, this signals to investors that the company has undergone some amount of due diligence and provides some assurance-though not an enforceable one-against fraud or misrepresentation by the company as to its value. In other words, to some degree the law firm's reputation stands in for material information about the company that investors would otherwise require. In the "reputational intermediary" model, law firms with established reputations provide a certification function for their clients, similar to that of well-reputed auditors. ${ }^{30}$ While the law firm-as-gatekeeper thesis has spawned considerable discussion, the empirical evidence for it is decidedly mixed. ${ }^{31}$

Taking instead a bottom-up approach to the question, Steven Schwarcz derived a third paradigm for the value provided by transactional lawyers. ${ }^{32}$ Based on a large-scale survey of both corporate clients and their outside counsel, Schwarcz concluded that business lawyers primarily add value (if at all) by acting as regulatory compliance experts. ${ }^{33}$ More precisely, law firms assist clients with major corporate transactions principally by navigating both client-specific and transaction-specific regulatory concerns. ${ }^{34}$ While Gilson had dismissed the importance of regulatory issues in corporate transactions, ${ }^{35}$ Schwarcz's work puts such concerns back at the center of transactional practice. ${ }^{36}$

30. Adopting a much broader definition of transactional law than Gilson, George Dent has proposed that business lawyers act as "enterprise architects" for their corporate clients. See George W. Dent, Jr., Business Lawyers as Enterprise Architects, 64 BUS. L. 279, 281 (2009) (arguing the lawyer's role in avoiding business obstacles is of greater importance than his or her role as transaction-cost engineer). While Gilson's model rests on the paradigm transaction of the corporate acquisition, Dent's view encompasses all of business law, and in particular transactions involving long-term business relationships such as joint ventures and venture capital investments. Because these ongoing relationships are characterized by incomplete contracting, Dent argues that lawyers provide a wider range of services than those involved in transaction-cost engineering, including balancing the client's interests across many transactions and navigating extra-contractual norms of trust and cooperation among the business people. Though this Article's hypothesis of the value provided by elite law firms reasonably extends to Dent's broader vision of transactional practice, for ease of discussion the Article's coverage is limited to Gilson's narrower scope, consisting of major corporate transactions involving the transfer of a capital asset, such as mergers and acquisitions and financing arrangements. See Gilson, supra note 24, at 249 (defining a transaction as the transfer of a capital asset).

31. See, e.g., Royce de R. Barondes et al., Underwriters' Counsel as Gatekeeper or Turnstile: An Empirical Analysis of Law Firm Prestige and Performance in IPOS, 2 CAP. MKTS. L.J. 164, 165 (2007) (finding support for the hypothesis that higher-quality law firms preserve some independence relative to the issuer in IPOs); Michael Bradley et al., Lawyers: Gatekeepers of the Sovereign Debt Market?, 38 INT'L. REV. L. \& ECON. 150, 162 (2014) (failing to find evidence that law firms act as reputational intermediaries in the sovereign debt markets). See generally Jonathan M. Bamett, Certification Drag: The Opinion Puzzle and Other Transactional Curiosities, 33 J. CORP. L. 95 (2006) (reviewing the "mixed and occasionally even contrary empirical results" on the performance of reputational intermediaries).

32. See Steven L. Schwarcz, Explaining the Value of Transactional Lawyering, 12 STAN. J.L. BUS. \& FIN. 486,500 (2007) (providing survey evidence that transactional lawyers primarily add value by reducing regulatory costs).

33. Id.

34. Id.

35. See Gilson, supra note 24 , at 247 (noting that business lawyers often operate in areas with minimal or no regulation).

36. Despite their differing emphases, there is likely to be considerable overlap in the transactionengineering and regulatory-expertise paradigms in practice, where, for example, lawyers seek to minimize the impact of regulatory concerns on transaction surplus. Gilson's theory sought a purely private-ordering role for lawyers that creates value; that is, a raison d'être for transactional lawyers in the absence of regulation. See Gilson, supra note 24 , at $246-47$ (describing his goal as identifying "a purely private ordering role for" transactional lawyers). Yet Gilson would readily acknowledge that when lawyers seek to minimize the costs imposed on a 


\section{B. The Value of Transactional Lawyers: What's Missing}

There are thus three broad paradigms for the role lawyers play in major corporate transactions: transaction-cost engineer, reputational intermediary, and regulatory expert. Each one resonates as being clearly and intuitively correct; ${ }^{37}$ these are not conflicting hypotheses among which we must choose. Yet the picture they collectively provide remains incomplete. In particular, they fail to fully account for one of the most salient features of current transactional practice: the overwhelming market share for major corporate transactions held by top-tier law firms. ${ }^{38}$ For such "mega-deals," we can count on one hand the number of firms that dominate the market for each type of transaction. ${ }^{39}$

Table 1: Combined Market Share of Top Five Law Firms By Transaction Type: U.S. Market (2014). ${ }^{40}$

\begin{tabular}{|l|c|c|}
\hline \multicolumn{1}{|c|}{ Transaction Type } & $\begin{array}{l}\text { \% Market Share of } \\
\text { Top 5 Firms by Deal } \\
\text { Volume } \\
\text { [Combined Volume } \\
\text { USD] }\end{array}$ & $\begin{array}{l}\text { \% Market Share of } \\
\text { Top 5 Firms by Deal } \\
\text { Count } \\
\text { [Combined Deal } \\
\text { Count] }\end{array}$ \\
\hline $\begin{array}{l}\text { US Corporates } \\
\text { Issuer Advisers }\end{array}$ & $30.4 \%$ & $25.5 \%$ \\
\hline [\$403 billion] & {$[879]$} \\
$\begin{array}{l}\text { US Corporates } \\
\text { Manager Advisers }\end{array}$ & $43.6 \%$ & $37.8 \%$ \\
\hline [\$602 billion] & {$[1003]$} \\
$\begin{array}{l}\text { US High Yield } \\
\text { Issuer Advisers }\end{array}$ & $29.1 \%$ & $22.6 \%$ \\
\hline
\end{tabular}

transaction by regulatory concerns, they are engaged in a form of transaction-cost engineering.

37. Of course, the degree to which each theory carries explanatory weight in practice depends highly on the particular transactional context.

38. See Hoffman \& Smith, supra note 3, at B1 (noting that, in the first half of 2014, the top five law firms held more than $75 \%$ of the U.S. mergers and acquisitions market share by deal dollar value).

39. See id. (describing how a small number of firms dominate this type of transaction).

40. Data compiled from the Global Legal Advisor: League Tables, BloOMBERG (July 1, 2015), http://www.bloomberg.com/professional/content/uploads/sites/4/Bloomberg-H1-2015-Global-LegalAdvisers.pdf. The figures for M\&A advisers were adjusted to correct for double-counting in advisory roles. 


\begin{tabular}{|l|c|c|}
\hline $\begin{array}{l}\text { US High Yield } \\
\text { Manager Advisers }\end{array}$ & $63.5 \%$ & $58.2 \%$ \\
\hline $\begin{array}{l}\text { US Syndicated Loans } \\
\text { Issuer Advisers }\end{array}$ & {$[\$ 214$ billion] } & {$[411]$} \\
\hline $\begin{array}{l}\text { US Syndicated Loans } \\
\text { Manager Advisers }\end{array}$ & {$[\$ 22111$ billion] } & $24.4 \%$ \\
\hline $\begin{array}{l}\text { US M\&A } \\
\text { Acquirer Advisers }\end{array}$ & {$[\$ 936$ billion] } & {$[107]$} \\
\hline $\begin{array}{l}\text { US M\&A } \\
\text { Seller Advisers }\end{array}$ & $24.7 \%$ & $54.9 \%$ \\
\hline US M\&A & {$[\$ 215$ billion] } & {$[695]$} \\
\hline \begin{tabular}{l} 
Target Advisers \\
\hline
\end{tabular} & $28.9 \%$ & $21.2 \%$ \\
\hline
\end{tabular}

The market concentration of elite firms aligns poorly with existing theories of corporate value. Take the example of the sale of a large public company. If Gilson's transaction-cost engineering hypothesis were the only plausible source of law firm value, then the seller should hire the most expensive law firm only if the company were faced with a truly novel problem, such as devising a new transaction structure in response to a recent regulatory change. For a transaction such as the sale of a large public company, the mechanisms for allocating risks efficiently between the parties have long since been devised, as Gilson freely acknowledges, ${ }^{41}$ through contractual provisions such as representations and warranties, closing conditions, earnouts, termination rights, break-up fees, and so forth. Rather than seeing the same top-tier law firms used over and over again for the same type of transaction, we would instead expect to see the top-tier firms used for the first-or first few-of each type of transaction. For subsequent transactions, the work could safely be relegated to lower-ranked (cheaper) firms, no matter how large the transaction. Instead we observe that the size of the transaction correlates closely with the

41. See Gilson, supra note 24 , at 257 ("[T] he general contents of the [acquisition] agreement have by now become pretty much standardized."). 
quality or ranking of the law firms used by the party, regardless of the novelty or complexity of the deal. ${ }^{42}$

The reputational-intermediary hypothesis is even less suited to the observed pattern of elite law firm use. Recall that, under this hypothesis, the intermediary's reputation acts as a substitute for information about the company. A law firm's good reputation thus creates value only to the extent that a party to the transaction or third-party beneficiary thereof-such as potential investors in an IPO-lacks reliable, material information about the company at issue. For a merger of equals between two major public companies, however, a law firm's reputation would be of little benefit to the parties, given the relative surfeit of available information about each. For such transactions, the reputationalintermediary hypothesis would predict that the parties would hire lesser law firms. Yet, these are precisely the sorts of transactions for which law firms with the most established reputations are routinely engaged.

The regulatory expert hypothesis fares the best among the three, as it does not predict the opposite of the observed pattern of law firm usage. And yet it does not fully account for this pattern. Continuing with the example of the sale of a large public company, it is certainly the case that any major corporation today faces a highly complex regulatory environment. Yet if that is so, the corporation would be best served by simply relying on the law firm that is most familiar with it and its specific regulatory concerns (its relationship firm), rather than on the most elite firm, with whom the company may have had little or no prior dealings. Again, the public-company merger is a well-trodden path, and though regulatory hurdles are involved, they are no longer novel or mysterious. ${ }^{43}$ Stated differently, the firm-specific regulatory costs likely outweigh the transaction-specific regulatory costs. Any competent law firm with a transactional practice could therefore fit the bill, and one that is intimately familiar with the company's particular regulatory issues would therefore seem best suited to the transaction. Yet this is not what we observe. For a major merger, the company will tend to engage one of the handful of top firms that specialize in that type of transaction, rather than its relationship firm. ${ }^{44}$ What, then, best explains this pattern of law firm selection? This is the task to which the Article turns in Part III. 45

42. See Jeffrey Manns \& Robert Anderson IV, The Merger Agreement Myth, 98 CoRNELL L. REV. 1143, 1150,1155 (2013) (stating that "almost all sizable transactions involve elite law firms" and noting "the almost universal use of a prominent law firm for large-scale transactions").

43. See Gilson, supra note 24 , at 247 (claiming that "business lawyers frequently function in a world in which regulation has made few inroads" and where "there is virtually no law to apply").

44. See supra note 42 and accompanying text (discussing the correlation between the size of the transaction and the quality of the law firm involved).

45. Before proceeding, it is worth dismissing-or, rather, correctly identifying —an alternative hypothesis for why elite law firms are breaking from the pack when it comes to major corporate transactions. The scholarly and practitioner literatures frequently refer to "star" lawyers or teams of lawyers for which clients will pay extraordinary fees. See John C. Coates et al., Hiring Teams, Firms and Lawyers: Evidence of the Evolving Relationships in the Corporate Legal Market, 36 L. \& SOC. INQUIRY 999, 1028 (2011) (stating clients view lawyers as a critical resource and will switch firms if a specific lawyer leaves). These legal geniuses are apparently so sought after that they, and therefore the law firms at which they practice, are able to command above-market rents. This story of individual or team talent is simply the legal services equivalent of the economic principle that the returns to top talent have increased dramatically as a result of globalization and technological change. See Sherwin Rosen, The Economics of Superstars, 71 AM. ECON. REV. 845, 845 (1981) (describing the contemporary phenomenon of a small number of individuals earning a disproportionate share of the income for certain types of 


\section{A NEW THEORY OF LAW FIRM VALUE: AGGREGATING MARKET INFORMATION}

Whether implicitly or explicitly, the existing paradigms of transactional lawyer value all reflect the notion that law firms gain a valuable advantage by repeatedly performing the same types of transactions. As high-volume players for a particular transaction, they acquire some skill or characteristic that cannot easily be replicated by firms that are relative novices to the game. The three paradigms simply disagree on what that particular skill or characteristic is. Under Gilson's transaction-cost engineering hypothesis, repeat-player law firms gain a keen understanding of the risk-allocation and information-eliciting devices involved in that type of transaction. ${ }^{46}$ Under the reputational-intermediary hypothesis, law firms over time develop a reputation for accurately representing what they know (and do not know) about their client to third parties, including the client's transaction counterparty, potential investors, and regulators. Under the regulatory expertise hypothesis, experience with a given transaction type provides a keen appreciation for the regulatory challenges it presents and how best to manage them.

As this Part demonstrates, repetition provides law firms with yet another valuable advantage: knowledge of the ever-changing and ever-expanding set of value-increasing terms for that particular transaction and of their market "price." The case for this missing piece of the value puzzle is set forth in Section III.B below, through three fundamental claims relating to certain complex, bilaterally-negotiated ${ }^{47}$ corporate transactions: (1) in

services). The latter has become a standard explanation for the extraordinary compensation paid to top entertainers, athletes, and corporate executives in a globalized economy. The top law firms earn above-market rents, we learn, simply because they are able to identify and hire the most legal superstars. Among transactional lawyers, for example, such superstars would no doubt include Marty Lipton, the inventor of the "poison pill" antitakeover device, which single-handedly stemmed the tide of the 1980s' hostile takeover wave and revolutionized the practice of mergers and acquisitions in the United States. See Michael J. Powell, Professional Innovation: Corporate Lawyers and Private Lawmaking, 18 L. \& SOC. INQUIRY 423, 433-41 (1993) (describing the development of the poison pill at Wachtell Lipton and the firm's efforts to publicize it).

As applied to law firms, the superstar theory is merely a particularly stark instance of either the transaction-cost engineering hypothesis or the regulatory expertise hypothesis, or both. Star lawyers are described as outstanding problem solvers, yet the problems they address can, in practice, be classified as minimizing transaction costs, addressing regulatory concerns, or a combination of the two. What still requires elucidation are the precise conditions under which clients require the services of a superstar lawyer or superstar team of lawyers. Again, well-established corporate transactions such as routine, public-company mergers and acquisitions seem ill-suited for the services of superstar lawyers. Thus, despite its intuitive appeal, the superstar theory-like its parent theories of transaction-cost engineering and regulatory expertise-fails to fully account for elite law firms' dominance in major corporate transactions. The superstar theory also falters as an account of the current law firm landscape in that individual lawyers having a dramatic, innovative impact on a particular transaction type or practice area are, in practice, likely to be vanishingly rare.

46. Gilson, supra note 24.

47. The remainder of this Part assumes that the transaction and the agreements through which it is effected are negotiated between two parties, referred to as the counterparties. Though such agreements will be referred to as bilateral, the number of parties bound by the agreement or having rights under the agreement need not be limited to two. In fact, most financing transactions ultimately bind many investors or grant such investors rights as third-party beneficiaries, but in practice are negotiated solely between the company and the large financial institution serving as the lead underwriter or arranger. At the opposite end of the spectrum from the complex, highly negotiated bilateral agreements at issue in this Article is the consumer contract of adhesion (such as a clickthrough license for a popular software product). The take-it-or-leave-it terms of such contracts are not negotiated at all, and bind a very large, dispersed group of unsophisticated consumers. See generally Ronald J. Gilson et al., Contract and Innovation: The Limited Role of Generalist Courts in the Evolution of Novel Contractual Forms, 
order to maximize their surplus from transactional bargaining, clients require access to market information-that is, access to the full set of terms of recent comparable transactions; (2) such market information is often private; and (3) high-volume law firms have the best access to market information. As will be shown below, certain transactions are characterized either by constant innovation in terms or by rapidly changing market prices, including for non-price terms. For such transactions, the parties cannot count on market competition to provide them with the payoff-maximizing set of deal terms; they must instead look to market information to improve their bargain.

\section{A. The Need for Market Information}

Over time, certain types of contracts can become commoditized, by operation of the market or even by regulatory fiat. Consumer insurance contracts, for example, may have terms that are substantively identical from one insurer to the next and are never negotiated with the consumer. Uniform terms and the absence of bargaining make the contracting process a simple exercise: the consumer need only look up the going market price and decide whether or not to transact. ${ }^{48}$ Whether corporate transactions are becoming or should become commoditized is the subject of much commentary and, among law firms, considerable angst. Every category of corporate transaction already presents some degree of standardization, as reflected in the recurrence of "boilerplate" provisions, for instance. ${ }^{49}$

Yet that is a far cry from commoditization. At any given time, there is some subset of corporate transactions that lies far on the spectrum from commoditized agreements. Such transactions tend to be heavily negotiated on a bilateral basis, in clear contrast to consumer contracts of adhesion. Though there is significant overlap among merger agreements, for example, in the end each agreement presents a unique combination of terms and unique variations in such terms because they are tailored to some degree to the particular target company and the counterparties and, as we will see, to current market conditions. ${ }^{50}$ The parties expend significant resources negotiating the deal terms, and for reasons discussed further below, they expect that the final agreement will depend heavily on the outcome of the negotiation process. For the remainder of this Article, references to "corporate transactions" will be to negotiated, bilateral transactions of this type. The need to bargain in such transactions creates strong ex ante incentives for the parties to acquire information that will maximize their payoff. As shown below, the combination of novel deal term generation and rapid shifts in the set of "market" terms for certain transactions explains why market information is so valuable to transaction counterparties.

88 N.Y.U. L. REV. 170 (2013) (noting how the number of "traders" affects the contract terms).

48. This is not to suggest that such contracts are necessarily efficient. A growing literature identifies conditions under which such contracts of adhesion do not maximize social welfare. See, e.g., Russell Korobkin, Bounded Rationality, Standard Form Contracts, and Unconscionability, 70 U. CHI. L. REV. 1203, 1233 (2003) (disputing the classic law and economics doctrine that sellers are incentivized to offer only efficient contract terms to consumers, on the grounds that consumers can only take into account a limited number of contract terms when making purchasing decisions).

49. See generally Stephen J. Choi \& G. Mitu Gulati, Contract as Statute, 104 MICH. L. REV. 1129 (2006) (discussing the characteristics and importance of "boilerplate" contract provisions).

50. See generally Albert Choi \& George Triantis, Market Conditions and Contract Design: Variations in Debt Contracting, 88 N.Y.U. L. REV. 51 (2013) (noting that debt contracts must be tailored to the borrower). 


\section{Novel Deal Terms: The Ever-Expanding Bargaining Frontier}

Regardless of their degree of regulatory overlay, major bilateral transactions are predominantly characterized by privately negotiated terms. ${ }^{51}$ What, then, determines the scope of the parties' bargain? In most cases, the parties should consider all value-increasing terms, that is, all terms that would increase the parties' joint surplus from the transaction, regardless of how that surplus is ultimately distributed between them. ${ }^{52}$ Yet theoretical accounts of bargaining fail to acknowledge that the set of value-increasing terms may be far from obvious. There is no fixed set of deal terms for the parties to negotiate: the list is jointly determined by the parties and can be expanded or contracted virtually at will..$^{53}$

Crucially, the recent thrust has been decidedly toward expansion for certain types of transactions. ${ }^{54}$ Whether or not lawyers are partly to blame, the set of terms considered open to negotiation in these major U.S. transactions appears to be growing both continually and at an increasing clip. New terms are constantly being introduced-whether to accommodate regulatory developments, changing market conditions, or party-specific needs-and at a faster pace than obsolete terms are discarded. Complex corporate transactions thus commonly result in negotiations over hundreds of terms.

This seemingly exponential growth in deal terms may plausibly be driven by several factors. First, the substantive complexity of financial instruments and transactions has increased dramatically in recent decades. ${ }^{55}$ It should come as no surprise, then, that the legal manifestations of modern finance in transactional agreements are themselves increasingly complex. ${ }^{56}$ Securitization transactions, for example, result in an impressive array of lengthy, complex agreements. ${ }^{57}$ Second, regulation is also increasing in complexity, prompting novel deal terms and deal structures. ${ }^{58}$ Third, as technology has

51. See Victor Fleischer, Regulatory Arbitrage, 89 TEX. L. REV. 227, 239 (2010) (arguing that even regulatory constraints provide an opportunity for lawyers to innovate in structuring transactions).

52. Even if a particular term would help one party and harm the other, it is nonetheless value-increasing if it helps the one party more than it harms the other. In this case, the parties should be able to reach a deal that includes the term in question and that makes them both better off, or at least does not make any party worse off: the party that is made better off by the term at issue can simply offer to trade something worth at least as much as the harm suffered by the other party.

53. See, e.g., Libeau v. Fox, 880 A.2d 1049, 1056 (Del. Ch. 2005), judgment entered, (Del. Ch. July 9, 2005), aff'd in part, rev'd in part, 892 A.2d 1068 (Del. 2006) ("When parties have ordered their affairs voluntarily through a binding contract, Delaware law is strongly inclined to respect their agreement, and will only interfere upon a strong showing that dishonoring the contract is required to vindicate a public policy interest even stronger than freedom of contract.").

54. See Neal H. Brockmeyer, M\&A Practice in the Early Years, 17 DEAL PoINTS 1, 7 (Winter 2012) (noting that "purchase agreements were much shorter" for mergers and acquisitions in previous decades).

55. See generally Steven L. Schwarcz, Regulating Complexity in Financial Markets, 87 WASH. U. L. REV. 211 (2009) (examining the complexities of the modern financial markets); see also Henry T.C. Hu, Misunderstood Derivatives: The Causes of Informational Failure and the Promise of Regulatory Incrementalism, 102 YALE L. J. 1457,1458 (noting the "unprecedented rate" of innovation in financial products).

56. See Charles M. FoX, Working With ContRacts: What law School Doesn't Teach You 74 (2d ed. 2008) (noting that the increased complexity of transactions has led to increasingly complex agreements).

57. See, e.g., Ameriquest Mortgage Securities Inc., Pooling and Servicing Agreement (Asset-Backed PassThrough Certificates Series 2005-R4) (May 1, 2005), http://www.sec.gov/Archives/edgar/data/1328390/000088 237705001419/d336334-ex4_1.htm (giving a typical example of a pooling and services agreement for assetbacked securities).

58. See Fleischer, supra note 51 , at 239 (discussing how lawyers can help minimize the impact of regulation by changing the legal structure of deals). 
improved, the costs associated with the production and sharing of complex transactional agreements have declined. ${ }^{59}$ The switch from the typewriter to the word processor and from mail to email has significantly increased the rate at which agreements can be drafted and lowered the costs of negotiating and amending them. It is now cheaper and easier to create and negotiate longer transactional agreements with more specialized or tailored terms. Fourth, as law firms have increased in size, they have proved better able to manage more complex agreements - for example, by involving regulatory specialists to draft or negotiate specific provisions-and to innovate more, if only because they have more resources to devote to these tasks. Discussion of a fifth possibility-that law firms themselves are exogenously (and self-interestedly) responsible for the increase in the number of deal terms--is deferred until Section V.B below.

The preceding list of explanations for the surge in deal terms is unlikely to be exhaustive. Whatever the causes, the agreements governing certain transactions appear to comprise an ever-greater set of terms. This proliferation of new terms makes it difficult for uninformed parties to determine the bargaining frontier of value-increasing terms. Yet parties who are unaware of new, value-increasing terms are simply leaving money on the table in their negotiations. Further, even if the parties are aware of a new term, if they lack sufficient information to value it correctly, they will achieve less favorable bargaining outcomes. For transactions experiencing rapid innovation, access to market information should prove exceptionally valuable.

\section{Market Shifts in Non-Price Terms}

Other types of transactions, such as mergers and acquisitions, are heavily negotiated despite relatively little innovation in terms. ${ }^{60}$ Market information can be crucial even in such cases, because (1) the price of every transaction term can vary according to market conditions, yet (2) a party cannot simply assume that it will obtain the "market terms" in its own negotiations, even if the market is competitive. To see why, let us first define the "market price" of a particular transaction term as the average price ${ }^{61}$ of that term at a given point in time, holding all else constant, where the "price" of a term is the aggregate value

59. See Brockmeyer, supra note 54, at 7 (noting the delays in previous decades associated with typewritten agreements for M\&A transactions); see also FoX, supra note 56, at 122 (describing the effect of technological change on the drafting of transactional agreements).

60. See Gilson, supra note 24 , at 257 ("[T] he general contents of the [acquisition] agreement have by now become pretty much standardized.")

61. We need not assume here that terms are priced uniformly and efficiently. Indeed, we should expect at least some dispersion in the pricing of a given transaction term by market participants. See, e.g., MAUREEN O'HARA, MARKET MiCROSTRUCTURE THEORY 53 (1995) (summarizing several information-based models of markets under which spreads occur). Transactional agreements are not commodities and accumulating evidence suggests that their terms are not perfectly priced. See Manns \& Anderson, supra note 42, at 1186 (concluding that deal protection provisions in merger agreements are not priced by the market); Stephen J. Choi \& G. Mitu Gulati, From Pigs to Hogs 1 (Jan. 7, 2015) (unpublished manuscript), http://ssm.com/abstract=2434272 (finding that differences in Greek sovereign bond contracts were priced by the markets at certain times, but not others); Victoria Ivashina \& Anna Kovner, The Private Equity Advantage: Leveraged Buyout Firms and Relationship Banking, 24 REV. FIN. STUD. 2462, 2463 (2011) (concluding that the view that leveraged loans are commodities is mistaken). Precisely because information about deal terms is scarce for certain complex corporate transactions, we should instead expect the same term to be priced slightly differently in different transactions. Nonetheless, the concept of a market price for any given deal term is a useful one. 
of what one party must trade in order to obtain the other party's consent to it. If a lender wants a borrower to accept a particular event of default in the loan agreement, for example, the price of that term might be a decrease in the interest rate. ${ }^{62}$

The key result is that every term in a transaction agreement-including every nonprice term ${ }^{63}$ - has a market price and changes in such market prices should affect the final deal reached by the parties in any particular negotiation. ${ }^{64}$ The notion that a transaction's price term varies with market conditions is intuitive. The price term in an IPO, for example, is the amount to be paid by the underwriter for the issuer's stock. We readily accept that such price terms are subject to change over time, according to shifts in supply and demand. The IPO market may get very "hot" during some periods and command high prices, but may "dry up" and yield lower valuations in others, for the very same types of issuers. ${ }^{65}$ Yet, as shown in recent work, non-price transaction terms can vary with market conditions as well. ${ }^{66}$ Moreover, even in a market with many participants on both sides of the transaction, the parties cannot simply assume that they will end up with the set of all valueincreasing terms - even when the set of such terms is known-instead, the outcome of their negotiation will depend in part on their relative bargaining power and their respective information about non-price terms. ${ }^{67}$

62. Note that in many (if not most) cases, we cannot readily assign a dollar value to the tradeoff, such as where the tradeoff is of one borrower-favorable "non-price term" for a lender-favorable "non-price term". This is not problematic for the proposed definition, however. Moreover, while some contract terms are binary in nature (i.e., they are either included in the agreement wholesale or not at all), others instead exhibit a discrete or continuous range of values, whether qualitative or quantitative (such as the interest rate, or a covenant that can be made more or less restrictive along a continuum). In all events, to the extent that a particular term affects the parties' respective expected payoffs from the transaction differentially, including the term in the agreement should result in a reasonably equivalent tradeoff.

63. Contracts scholars tend to distinguish between "price terms" and "non-price terms" in agreements. Similarly, business teams involved in corporate transactions commonly distinguish between "business" or "economic" terms and "legal" terms. While there is no clear principle for distinguishing between the two, price or business terms tend to capture the fundamental economic deal between the parties (and are therefore generally numeric), while non-price or legal terms are the remainder of the contractual provisions governing the transaction.

64. See Choi \& Triantis, supra note 50, at 71-72 (demonstrating how the non-price terms of debt contracts can vary with market conditions).

65. See Jean Helwege \& Nellie Liang, Initial Public Offerings in Hot and Cold Markets, 39 J. FIN. \& QUANTITATIVE ANALYSIS 541, 542 (2004) (concluding that hot IPO markets are the result of greater investor optimism, rather than greater firm growth prospects).

66. Choi \& Triantis, supra note 50, at 71-72; see WILLIAM WHELAN, LEVERAGED FINANCIAL MARKETS: A COMPREHENSIVE GUIDE TO HIGH-YIELD BONDS, LOANS, AND OTHER INSTRUMENTS 5 (William F. Maxwell \& Mark R. Shenkman eds., 2010) (noting that "the concept of 'market' [in a high-yield financing] evolves over time" and depends on several factors); Martin Fridson et al., Do Bond Covenants Affect Borrowing Costs?, $26 \mathrm{~J}$. APPLIED CORP. FIN. 79, 80 (2014) (finding evidence that the strength or weakness of bond covenants does not result in adjustments to bond prices).

67. A dominant strain of law and economics doctrine holds that changes in bargaining power should have no effect on the non-price terms of a contract. On this view, supply and demand in the market produce a single, efficient set of non-price terms for a given transaction type; the parties' relative bargaining power only leads to adjustments to the price term. See Albert Choi \& George Triantis, The Effect of Bargaining Power on Contract Design, 98 VA. L. REV. 1665, 1668 n.4 (2012) (compiling several examples of scholarly work in the law and economics vein assuming the absence of bargaining power with respect to non-price contract terms and critiquing this "irrelevance principle"). In contrast to this literature, Choi and Triantis have identified several conditions under which bargaining power can affect the non-price terms of various contracts, including the example used here of multi-stage negotiations. Id. at 1680-96; see also Manns \& Anderson, supra note 42, at 1174 ("[T]here is 
How do we explain this seeming paradox, that at any point in time there is a set of "market" terms for a particular transaction, yet the parties cannot count on the market to get them a deal on such terms? One explanation is that many transactions-including mergers and acquisitions and loan transactions-are negotiated in stages, ${ }^{68}$ with the price terms settled in the earliest stages (by the principals) and the non-price terms negotiated in later stages (primarily by counsel). ${ }^{69}$ The distinguishing feature of such multi-stage negotiations is that the price terms agreed to up-front are remarkably sticky: ${ }^{70}$ regardless of how negotiations over the non-price terms ultimately unfold, it is highly unlikely that the parties will adjust the price terms to which they originally agreed. ${ }^{71}$ This timing mismatch in the negotiation of price and non-price terms leaves room for bargaining power imbalances and market shifts to affect not only the price term but also the non-price terms. ${ }^{72}$ The parties will need to bargain over the non-price terms, creating incentives to acquire information that will help them determine (1) the expected payoff to each party of every transaction term, ${ }^{73}$ and (2) the value of the parties' respective outside options. ${ }^{74}$

in fact considerable variation in the deal-specific terms [of merger agreements] and that variation largely results from the relative leverage of the two parties.").

68. See Choi \& Triantis, supra note 67 , at 1690 (discussing bargaining power in two-stage negotiations). For leveraged-loans, the negotiation stages are as follows. First, the borrowing company solicits bids for financing from various lead arrangers. Such bids typically cover the price terms of the financing, as well as a subset of nonprice terms that the parties view as crucial to have agreed upon in advance. The second stage of negotiations begins once the borrower selects the winning lead arranger and signs a commitment letter with respect to the agreed-upon terms. At this point, the borrower and lead arranger negotiate all of the remaining terms of the loan transaction, to be reflected in the final credit agreement. See Ivashina \& Kovner, supra note 61, at 2469 (describing the transaction steps for a leveraged-loan financing for a private equity-sponsored acquisition).

69. Typically, the "business" teams will initially agree to the price terms-and perhaps a small subset of non-price terms deemed particularly fundamental-in a term sheet or letter of intent, for example. Subsequently, counsel will begin drafting the transaction agreements, leading to several rounds of negotiations over the remaining non-price terms. See Choi \& Triantis, supra note 67, at 1690 (describing how bargaining power plays out in the two stages of negotiations).

70. See id. (stating that where the deal price is set in the first stage of negotiations, non-price terms "are usually settled without adjustment to price"); Manns \& Anderson, supra note 42, at 1176 (stating that the price and other economic terms of a merger are agreed upon separately from negotiations over the legal terms, and that "the financial 'deal' is typically independent of the legal terms of the agreement").

71. See Choi \& Triantis, supra note 67 , at $1690-91$ (noting that while the parties could theoretically reopen negotiations over the price terms while negotiating the non-price terms, the "nonlegal costs" associated with doing so make it highly unlikely that this will occur).

72. Id. at $1680-86$.

73. A party's payoff from a transaction term is the net dollar value gain or loss to the party from including the term in the agreement. Where a term's payoff is uncertain, in that there are multiple potential payoffs, the expected payoff is the probability-weighted average of all possible payoffs from the term. In a corporate transaction, it is worth recalling that just as the capital asset to be transferred between the parties-the company to be sold, the amount to be loaned, etc.- -has an expected payoff to the parties, so do each of the other deal terms, including "legal" or "non-price" terms such as closing conditions, remedies for breach, choice of law clauses, and so forth.

74. A party's outside option for a given negotiation is its expected payoff from breaking off the current negotiations and retuming to the market to negotiate with another party. The parties' respective outside options affect the final deal they will reach-including whether they will reach a deal in the first place-because, in most bargaining contexts, how much a party should demand or give up for any particular term depends rationally on the value of its next best alternative. A party with a very good outside option compared to the other party has less incentive to reach a deal, and therefore, can demand better terms and try to capture most of the deal surplus from the other party. On the other hand, a party lacking a good outside option will be more eager to reach a deal, even 
Market information-that is, information about all of the terms of recent comparable transactions-fulfills precisely this role. ${ }^{75}$

\section{B. Market Information About Deal Terms Is Often Private}

Complex corporate transactions may thus involve an ever-expanding set of potentially negotiable terms, each of which is subject to market conditions. Yet it turns out that information about the pricing, prevalence, and even the existence of various deal terms often is not public, and therefore is not readily accessible to potential counterparties to a transaction. First, many large corporate deals are private. Transactions that do not involve a public company or otherwise trigger a public disclosure requirement under the securities laws will, absent unintentional leaks or voluntary disclosure, involve deal terms that remain entirely private. Only the counterparties and, to varying degrees, their respective advisors and service providers will know of the final deal reached on all points.

Second, the extent to which the terms of public deals are in fact publicly available is overstated. Consider again the consummate example of a public deal-the acquisition of a public company. Because the acquisition agreement must be filed with the Securities and Exchange Commission (SEC), certainly many deal terms-including the most material economic terms-will be available to the public. Yet even for such transactions, the parties never file the complete set of transaction documents with the SEC, as only the key agreements are required to be disclosed. ${ }^{76}$ The documents that are not filed may contain terms that even the parties themselves would view as highly significant, such as those relating to the background tax and regulatory structuring of the deal.

More importantly, even when they involve public companies, many transactions that would clearly be viewed as major transactions by virtue of their dollar amount nonetheless escape filing obligations entirely. For a corporation such as Wal-Mart, a $\$ 500$ million bank financing might not exceed the materiality threshold for mandatory disclosure under the securities laws, and thus would not require any of the transaction documents to be filed. ${ }^{77}$ The deal terms, which would be of considerable interest to comparable companies seeking financing, remain hidden from the market in such cases. Finally, because novel terms arise frequently, there is inevitably some delay in achieving widespread publicity and adoption of these terms. While information about a novel term will eventually trickle into the public sphere (through practitioner articles, public deals, etc.), until that time, counterparties negotiating a transaction may be entirely unaware of it.

\section{High-Volume Law Firms Have the Best Access to the Full Package of Deal Terms}

For many major transactions, then, real-time market information is both a valuable good and, because it is private, an excludable one. As repeat players, high-volume law firms have the best access to the full range of terms for recent transactions, through the

on relatively unfavorable terms. See supra note 9 (explaining outside options).

75. While the expected payoff to a party from a particular term need not be market-determined-it may be unique to the party-in many cases the market price of the term will be the best available information about the value of that expected payoff, particularly when the term is novel or complex.

76. See 17 C.F.R. $\$ 229.601$ (a)(4) (2011) (mandating disclosure of "material" agreements for companies registered under the Securities Exchange Act of 1934).

77. Id. 
sheer volume that they handle and their monopoly over the drafting of transaction agreements. ${ }^{78}$ While other market participants--such as the transaction parties themselves, the parties' in-house counsel, investment banks, accounting firms, and third-party services that compile and compare deal terms-all have varying exposure to and familiarity with deal terms, we should expect the transactional practices at elite law firms to have the most comprehensive access. Transactional lawyers are by definition assigned the task of negotiating the vast majority of deal terms and the exclusive tasks of drafting and maintaining the execution version of all transaction documents. They are the de facto deal constituency most intimately familiar with all of the final terms of such transactions. ${ }^{79}$

Transaction parties, by contrast, only have access to deal terms for their own prior transactions. Major transactions are rare in any individual corporation's life, compared to a large law firm's transactional practice. Management should thus tend to be relatively poorly informed as to both the current set of plausible deal terms for any particular transaction and their current pricing in the market. Importantly, the very same critique applies to in-house counsel. In examining companies' decisions of whether to "make or buy" 80 legal counsel for corporate transactions (i.e., whether to hire in-house counsel or to engage outside counsel), scholars have yet to note that in-house counsel is at a decided disadvantage relative to law firms when it comes to current market information. While large corporations may have teams of in-house lawyers with transactional experience, such lawyers necessarily lack exposure to changing market terms, and this disadvantage grows with the number of years they remain in-house.

Yet law firms are not the only repeat players for major corporate transactions. Various advisers and other service providers to the parties may also have exposure to a high volume of transactions, and of these, some-such as investment banks, accounting firms, and credit rating agencies-may be both sophisticated and keenly aware of market movements. ${ }^{81}$ Investment banks, in particular, specialize in helping clients to price transactions. ${ }^{82}$ Of all market participants involved in corporate transactions, they are the best known for their ability to track market movements and even time the markets to get clients the most favorable deal terms. Yet, investment banks' knowledge and experience with deal terms is largely centered on the price terms of a transaction (also referred to as the "business terms" or "economic terms"). In particular, they and other deal advisors lack law firms' complete access to the deal documentation, and in particular are less able to identify and interpret the non-price or "legal" deal terms. As drafters and keepers of the deal documentation across many clients, law firms are best positioned to maintain a repository of the full range

78. See John F. Coyle \& Joseph M. Green, Contractual Innovation in Venture Capital, 66 HASTINGS L.J. 133,142 (2014) ("[A]ttorneys at large law firms will typically have access to a significant number of existing contracts that may be mined for innovative provisions.").

79. See Gilson, supra note 24, at 257 ("[T]he business lawyer's role in corporate acquisitions is pervasive.").

80. See Schwarcz, supra note 16 (providing a detailed analysis on the tradeoffs between in-house and private counsel).

81. See Ronald J. Gilson \& Reinier H. Kraakman, The Mechanisms of Market Efficiency, 70 VA. L. REV. 549,620 (1984) (introducing the concept of "reputational intermediary" for market actors that, through repeat business, are able over time to establish reputations for certifying information about other actors).

82. See Jack Bao \& Alex Edmans, Do Investment Banks Matter for M\&A Returns?, 24 REV. FIN. STUD. 2286, 2312-13 (2011) (finding that a client's choice of investment bank for a merger or acquisition affects its returns from the transaction). 
of possible deal terms-both "business" and "legal." Thus, while we can safely posit that advisors such as investment bankers may have an advantage over transactional lawyers in pricing key economic terms, there is at least some subset of transaction terms for which law firms will have the advantage. 83 Finally, a market has recently developed for knowledge-management services that sell summary deal-term information. ${ }^{84}$ While the proliferation of such products confirms that deal-term aggregation and comparison are valuable functions, the risk that they will eventually usurp law firms' role in this regard is minimal, precisely because law firms have access to, and can make use of, private deals and other private market information.

\section{MARKET INFORMATION IN PRACTICE: A CASE STUDY}

Market information about transaction terms is thus both valuable and excludable, and the barriers to entry in acquiring it are high. The law firms that sell market information should therefore expect to be rewarded with persistent rents. Part IV uses a case study of the U.S. leveraged-loan market to illustrate how law firms can assist with term pricing. It begins with relevant background on leveraged-loan transactions and documentation. The pricing exercise is then illustrated through stylized cases in which a law firm's representation of the borrower may be value-adding, value-shifting, or value-decreasing, all with respect to the very same transaction term.

\section{A. Leveraged Loans: Background}

As a relative newcomer to the U.S. capital markets, the leveraged-loan market has experienced both tremendous growth in volume and liquidity and significant innovation in its legal terms. ${ }^{85}$ Leveraged loans are primarily characterized by two features: (1) they are

83. What of clients who are themselves repeat players for particular transactions? Where the investment bank is the client, for example, rather than the advisor, it inevitably relies on its knowledge of recent transactions. On the other side of the negotiating table, various categories of investors, including in particular private equity firms, are also high-volume participants in major corporate transactions such as mergers and acquisitions and leveraged financings. See generally Elisabeth de Fontenay, Private Equity Firms as Gatekeepers, 33 REV. BANKING \& FIN. L. 115 (2013) (arguing that reputable private equity firms render the debt markets more efficient). And yet, paradoxically, such investors appear to be the most likely to engage top-tier law firms for their transactions. See Steven M. Davidoff, The Failure of Private Equity, 82 S. CAL. L. REV, 481, 535-37 (2009) (demonstrating that the largest private equity firms tend to engage the same small group of elite, repeat-player law firms for their acquisition and financing transactions). Three explanations seem plausible. First, it may be that private equity firms are simply paying for law firms' knowledge of other clients' deal terms (even if confidentiality obligations prevent law firms from explicitly revealing one client's deal terms to another, law firms inevitably make use of this information in advising their clients and in negotiating deal terms). Second, precisely because they are sophisticated repeat players, investment banks and private equity firms are keenly aware of both the value of market knowledge and their specific lacunae in that regard. As discussed above, investment banks and private equity firms have less access to and knowledge of the "legal" terms of transaction agreements than law firms, yet are savvy enough to know that they can benefit from seeking out high-volume law firms for assistance with such terms. Third, private equity firms negotiate against investment banks for most of their acquisition and financing transactions and will therefore rely on repeat-player law firms precisely to counter investment banks' market knowledge.

84. Practical Law, Bloomberg Law, Xtract Research, The Deal, and many others, all include products that perform a function similar to the one this Article ascribes to elite transactional law firms, namely aggregating and comparing terms from recent large deals.

85. See generally Sung Eun (Summer) Kim, Managing Regulatory Blindspots, 32 YALE J. ON REG. 89 
extended to companies having a relatively high proportion of debt in their capital structure, and (2) they are intended to be syndicated. ${ }^{86}$ The lender group (or syndicate) typically consists of a highly diverse mix of banks and non-bank institutional investors. ${ }^{87}$ Postissuance, many of these loans are subsequently traded on an increasingly liquid secondary market.

Despite heavy secondary trading, leveraged loans are not treated as securities and therefore are not subject to federal securities regulation. ${ }^{88}$ This has two significant implications for our purposes. First, leveraged loans are issued privately, such that, unless the borrower is otherwise subject to securities reporting requirements, the loan documents will not be publicly available. Second, leveraged-loan transactions remain to this day very lightly regulated. As such, they are prime examples of complex, heavily negotiated, and highly tailored agreements, the terms of which remain largely private. Further, they are negotiated in stages, with the price terms-and certain non-price terms-set before the remainder of the non-price terms are negotiated, increasing the parties' need for market information on the individual non-price terms. ${ }^{89}$

The tremendous growth in the leveraged-loan market has been mirrored by tremendous innovation in terms. Leveraged-loan credit agreements saw a surge in novel provisions in the boom period preceding the 2007-2009 financial crisis and again during the crisis itself, when borrowers scrambled to renegotiate their loans and creatively navigate a difficult lending environment. While commentators frequently note the lack of innovation in many legal documents, ${ }^{90}$ leveraged-loan transactions provide an impressive counterexample. ${ }^{91}$ In the course of less than a decade, dozens of new provisions were

(2015) (assessing the regulation of leveraged loans).

86. Syndicated loans are typically underwritten or arranged by a single investment or commercial bank and ultimately funded by a large syndicate of lenders. Katerina Simons, Why Do Banks Syndicate Loans?, NEW ENG. ECON. REV. 45, 45-46 (Jan. 1993), http://www.bostonfed.org/economic/neer/neer1993/neer193c.pdf.

87. The non-bank institutional investors may include structured asset pools (referred to as collateralized loan obligations) designed to hold syndicated loans, insurance companies, pension funds, mutual funds, private debt funds, and sovereign wealth funds.

88. See Elisabeth de Fontenay, Do the Securities Laws Matter? The Rise of the Leveraged Loan Market, 39 J. CORP. L. 725, 747 (2014) (discussing the differing regulatory treatment of loans and bonds).

89. See supra Section III.A. 2 (discussing the implications of setting the price term first in multi-stage negotiations).

90. See generally, Mitu Gulati \& Robert E. SCOTT, THE THREe and a Half MinUte TRANSACtION: BOILERPLATE AND THE LIMITS OF CONTRACT DESIGN (2013) (identifying lawyers' puzzling failure to update a boilerplate provision in sovereign debt contracts, even in the face of negative court decisions); Marcel Kahan \& Michael Klausner, Standardization and Innovation in Corporate Contracting (Or "The Economics of Boilerplate"), 83 VA. L. REV. 713, 718-29 (1997) (describing the circumstances in which the use of boilerplate provisions provide economic benefits); Barak D. Richman, Contracts Meet Henry Ford, 40 HOFSTRA L. REV. 77 , 82 (2011) (characterizing the lack of contractual innovation by law firms as a form of Taylorism). For an overview of competing theories of contractual innovation, see generally Stephen J. Choi et al., The Dynamics of Contract Evolution, 88 N.Y.U. L. REV. 1 (2013) (comparing various contractual innovation theories).

91. See Allison A. Taylor \& Ruth Yang, Evolution of the Primary and Secondary Leveraged Loan Markets, in THE HANDBOOK OF LOAN SYNDICATIONS AND TRADING 21, 23-24 (Allison Taylor \& Alicia Sansone eds., 2007) (describing the origins and growth of the syndicated loan market). While we need not resolve why the leveraged-loan market witnessed such a high rate of contractual innovation, plausible contributors include the role of highly sophisticated participants (private equity firms on the borrower side and major investment banks on the lender side), rapidly changing market conditions and financing structures, the shift in composition of lending syndicates (from traditional commercial banks to structured asset vehicles and other institutional 
developed that, over time, became standard loan terms. ${ }^{92}$ As the drafters, and often the originators, of such provisions the select group of law firms handling most leveraged-loan financings were in the best position to price such terms for clients during the period of sustained innovation.

\section{B. Leveraged Loan Pricing Using Market Information: Application}

As leveraged-loan syndicates have increased in size and the secondary trading of leveraged loans has become routine, borrowers have faced greater obstacles to renegotiating their loan terms after the initial closing. A borrower may seek to renegotiate a loan's terms for any number of reasons, ${ }^{93}$ and such requests for amendments or waivers are relatively common. ${ }^{94}$ Importantly, the transaction costs involved with renegotiations increase with the size of the lender group and the amount of secondary trading among lenders: collective action problems arise as the number of lenders increases and the duration of their respective loan holdings decreases. ${ }^{95}$ Each lender has less incentive and ability to familiarize itself with the borrower and the loan terms, has more incentive to freeride on the monitoring efforts of other lenders, and has more incentive to hold out against otherwise value-increasing changes to the loan terms in the hopes of extracting a sidepayment.

Because the leveraged-loan market's surge in size and liquidity occurred so rapidly, this lender collective action problem manifested suddenly. Under the circumstances, a novel loan provision that would facilitate loan renegotiations without dramatically altering the relative leverage of the borrower and the lenders in such renegotiations would prove extremely valuable. This is precisely how the "yank-a-bank" provision was developed and began appearing in credit agreements for private leveraged-loan financings. The "yank-abank" is a contractual innovation in loan agreements that, among other uses, permits (but does not require) the borrower to replace any lender who votes against a proposed loan amendment simply by repaying that lender's share of the loan at par. ${ }^{96}$ Such a provision incentivizes lenders overall to vote in favor of loan amendments and decreases the

investors), and very light regulation.

92. Without the assistance of a law firm specializing in leveraged loans, a company seeking financing during this period would almost certainly be entirely unaware of "market flex," the "SunGuard clause," "excess cash flow prepayment step-downs," "equity cure rights," "covenant-lite," "amend-and-extend rights," "loan buyback Dutch auctions," and other novel provisions, and thus risk foregoing significant transaction value. See PRACTICAL LAW GLOSSARY, http://us.practicallaw.com/us-glossary (last visited Nov. 8, 2015) (describing these terms).

93. For example, the borrower may be motivated to seek a loan amendment to cure an unintentional and minor breach, to loosen the financial covenants in the credit agreement, to obtain permission to engage in an otherwise prohibited transaction such as a merger or acquisition, to extend the maturity of the loans, and so forth.

94. See Marcel Kahan \& Bruce Tuckman, Private Versus Public Lending: Evidence From Covenants, in THE YEARBOOK OF FIXED INCOME INVESTING 253, 253-74 (John D. Finnerty \& Martin S. Fridson eds., 1995) (noting that "private debt . . . require[s] more frequent renegotiation than public debt").

95. Arthur E. Wilmarth, Jr., The Transformation of the U.S. Financial Services Industry, 1975-2000: Competition, Consolidation, and Increased Risks, 2002 U. ILL. L. REV. 215, 378 (2002) (noting that syndicated loans have fewer covenants than traditional bank loans).

96. See Richard Wight et AL., The LTSA's Complete Credit Agreement Guide 575-76 (2009) (describing the use of the yank-a-bank provision to replace lenders who do not consent to credit agreement waivers or amendments). 
likelihood that lenders can successfully extract hold-up payments from the borrower in exchange for consenting to the amendment.

All else being equal, the yank-a-bank provision increases the borrower's leverage visà-vis lenders in renegotiations. Then, under a credit agreement containing a yank-a-bank provision, the borrower should end up paying out less to the lenders in aggregate (either in the form of amendment fees or concessions in the loan agreement) when it renegotiates loan terms, making the borrower better off at the lenders' expense. At the same time, however, the yank-a-bank provision also provides a benefit to the lenders that may or may not offset this effect. While a loan is outstanding, events occur that are unanticipated by either side and therefore by the loan agreement; in some cases, an amendment to the loan would benefit both the borrower and the lenders. ${ }^{97}$ Thus, preventing individual lenders from blocking or delaying such loan amendments is in the interest not only of the borrower but also of the lenders taken as a group.

Ultimately, whether it is in the lenders' interests to adopt the yank-a-bank provision in a credit agreement - thereby both lowering the transaction costs of loan renegotiations and granting the borrower greater leverage in such renegotiations-depends on contingencies such as the expected size of the lender group, the expected amount of secondary trading in the loan, the likelihood that the loan will have to be renegotiated, and the probability of good behavior by the borrower. Whether including the term proves to be value-increasing will thus largely depend on whether these contingencies are correctly taken into account when pricing the yank-a-bank provision at the time the credit agreement is negotiated. The four cases below, all relating to the yank-a-bank provision, illustrate some of the ways in which transactional lawyers' interventions in deal negotiations could affect the aggregate surplus generated by the deal. In each case, the relevant comparison is between the outcome when the client employs a law firm with market knowledge-an "informed law firm"- and when the client employs a law firm or in-house counsel without market knowledge.

\section{Case 1: The Informed Law Firm's Intervention Is Value-Increasing by Informing the Counterparties of a Mutually Beneficial Term}

First assume a high-quality, well-behaved borrower, such that if the borrower proposes a loan amendment during the life of the loan, the amendment is likely to be valueincreasing for the lenders in aggregate. The lenders should thus be happy to grant the borrower additional bargaining leverage ex ante in loan renegotiations in order to avoid lender holdout problems that might preclude such an amendment or make it costlier. Assume also that the lender syndicate is expected to be very large, with substantial secondary trading of the loan, such that lender collective action problems would normally be severe. Under such circumstances, we can safely assume that both the borrower and the lenders would be made unambiguously better off by including a yank-a-bank provision in their credit agreement. More specifically, their respective expected payoffs from the

97. Assume, for example, that the borrower unintentionally defaults on the loan due to a mere technicalitysuch as failing to deliver its financial statements to the correct address for the administrative agent-rather than due to deteriorating performance or bad borrower behavior. If the borrower's credit risk remains fundamentally sound, it is likely to be in the lenders' interests to waive the borrower's default to avoid accelerating the loan and triggering the borrower's bankruptcy, which would likely significantly decrease the value of their loan holdings. 
leveraged-loan transaction would be higher if the term were included, as reflected in the following sample dollar values:

Table 2: Case 1

\begin{tabular}{|c|c|c|c|}
\hline & $\begin{array}{c}\text { Gross } \\
\text { expected } \\
\text { payoff w/o } \\
\text { yank-a-bank } \\
\text { provision }\end{array}$ & $\begin{array}{c}\text { Gross expected } \\
\text { payoff w/yank- } \\
\text { a-bank } \\
\text { provision }\end{array}$ & $\begin{array}{c}\text { Change in } \\
\text { expected payoff } \\
\text { from adding } \\
\text { term to credit } \\
\text { agreement }\end{array}$ \\
\hline Borrower & $\$ 10 \mathrm{M}$ & $\$ 12 \mathrm{M}$ & $+\$ 2 \mathrm{M}$ \\
\hline Lenders & $\$ 10 \mathrm{M}$ & $\$ 10.5 \mathrm{M}$ & $+\$ 0.5 \mathrm{M}$ \\
\hline
\end{tabular}

Assume that, in the absence of high-quality financing counsel, the parties would be entirely unaware of the yank-a-bank provision. So long as the additional cost of hiring an informed law firm compared to an uninformed firm does not outweigh the gains, both parties are better off-net of legal fees-as a result of including the provision in the credit agreement. By making the parties aware of a novel term, the informed law firm has increased the joint surplus from the transaction.

2. Case 2: The Informed Law Firm's Intervention is Value-Increasing by Assisting with the Pricing of a Term

Now assume a lower-quality, more opportunistic borrower, facing a smaller lender group (and therefore lower transaction costs of renegotiations). Under these circumstances, giving the borrower more leverage in renegotiations should come at a slight cost to the lenders, all else being equal:

Table 3: Case 2

\begin{tabular}{|c|c|c|c|c|}
\hline & $\begin{array}{c}\text { Gross } \\
\text { expected } \\
\text { payoff w/o } \\
\text { yank-a- } \\
\text { bank } \\
\text { provision }\end{array}$ & $\begin{array}{c}\text { Gross } \\
\text { expected } \\
\text { payoff w/ } \\
\text { yank-a- } \\
\text { bank } \\
\text { provision }\end{array}$ & $\begin{array}{c}\text { Change in } \\
\text { expected } \\
\text { payoff from } \\
\text { adding term } \\
\text { to credit } \\
\text { agreement }\end{array}$ & $\begin{array}{c}\text { "Price" range } \\
\text { at which } \\
\text { parties } \\
\text { should agree } \\
\text { to add term } \\
\text { to credit } \\
\text { agreement }\end{array}$ \\
\hline Borrower & $\$ 10 \mathrm{M}$ & $\$ 12 \mathrm{M}$ & $\begin{array}{c}\$ 1-2 \mathrm{M} \text { in } \\
\text { borrower } \\
\text { concessions }\end{array}$ \\
\hline Lenders & $\$ 10 \mathrm{M}$ & $\$ 9 \mathrm{M}$ & $-\$ 1 \mathrm{M}$ & \\
\hline
\end{tabular}


Notwithstanding that the lenders' expected payoff from the yank-a-bank provision is negative, they should agree to include the term so long as the borrower makes other concessions in the credit agreement worth at least $\$ 1$ million to the lenders. The borrower should agree to include the term so long as the concessions demanded by the lenders do not exceed $\$ 2$ million in value. At any "price" within that range (net of legal fees), the parties will achieve a jointly value-increasing deal. But notice that this requires the parties (1) to be aware of the existence of the yank-a-bank provision, (2) to correctly determine their expected payoffs from including the yank-a-bank provision in the credit agreementrequiring informed predictions as to the borrower's behavior, the likelihood of renegotiation, the size of the lender group, the amount of secondary trading, etc.- and (3) to identify provisions in the credit agreement of equivalent value to the agreed-upon "price" of the yank-a-bank provision. The third step is required given that, as discussed above, the price terms for leveraged loans are typically fixed at the outset of the negotiations, such that negotiations over non-price terms must be effected through adjustments to other nonprice terms, rather than to the price terms. As all three tasks require experience with current market conditions, an informed law firm can bring the parties within the bargaining range of a value-increasing deal for both, net of legal fees.

\section{Case 3: Informed Law Firm's Intervention is Merely Value-Shifting}

Assume all of the same facts as in Case 2, except that the parties are already aware of the yank-a-bank provision, and would, using uninformed counsel, have arrived at a valueincreasing deal by including the provision in the credit agreement in exchange for concessions by the borrower worth $\$ 2$ million to the lenders. Now imagine that the borrower's law firm correctly informs the borrower that, based on its review of recent transactions, the "market" price of the yank-a-bank provision for similar credit facilities is only $\$ 1.5$ million-that is, the borrower's outside option is a credit agreement that includes the yank-a-bank provision in exchange for only $\$ 1.5$ million in borrower concessions. The borrower will now negotiate harder for this provision, for example by threatening to break off negotiations and exercise its outside option and might thus successfully bring the price down to $\$ 1.5$ million (or lower if the lenders are uninformed as to the true market price). 
Table 4: Case 3

\begin{tabular}{|c|c|c|c|c|c|}
\hline & $\begin{array}{c}\text { Gross } \\
\text { expected } \\
\text { payoff } \\
\text { w/o } \\
\text { yank-a- } \\
\text { bank } \\
\text { provisio } \\
\text {-n }\end{array}$ & $\begin{array}{c}\text { Gross } \\
\text { expecte } \\
\text { payoff } \\
\text { w/ } \\
\text { yank-a- } \\
\text { bank } \\
\text { provisi- } \\
\text { on }\end{array}$ & $\begin{array}{c}\text { Change in } \\
\text { expected } \\
\text { payoff } \\
\text { from } \\
\text { adding } \\
\text { term to } \\
\text { credit } \\
\text { agreement }\end{array}$ & $\begin{array}{c}\text { "Price" at } \\
\text { which } \\
\text { parties } \\
\text { would agree } \\
\text { to add term } \\
\text { w/o law } \\
\text { firm } \\
\text { intervention }\end{array}$ & $\begin{array}{c}\text { "Price" at } \\
\text { which } \\
\text { parties } \\
\text { would agree } \\
\text { to add term } \\
\text { w/ law firm } \\
\text { intervention }\end{array}$ \\
$\begin{array}{c}\text { Borrow } \\
\text {-er }\end{array}$ & $\$ 10 \mathrm{M}$ & $\$ 12 \mathrm{M}$ & $+\$ 2 \mathrm{M}$ & $\begin{array}{c}\$ 2 \mathrm{M} \text { in } \\
\text { borrower } \\
\text { concessions }\end{array}$ & $\begin{array}{c}\text { \$1.5M in } \\
\text { borrower } \\
\text { concessions }\end{array}$ \\
\hline Lender & $\$ 10 \mathrm{M}$ & $\$ 9 \mathrm{M}$ & $-\$ 1 \mathrm{M}$ & & \\
\hline
\end{tabular}

With a deal at $\$ 1.5$ million for the yank-a-bank provision (compared to $\$ 2$ million), the informed law firm's intervention has clearly made the borrower better off. Yet all that has occurred is a shifting of deal surplus from the lenders to the borrower: the total gross surplus to the parties remains unchanged relative to the deal that they would have reached on their own. Thus, taking into account legal fees, the informed law firm's intervention has actually reduced net social surplus.

\section{Case 4: Informed Law Firm's Intervention is Value-Decreasing for Both Parties}

Finally, assume a low-quality borrower and a very small lender group, with no secondary trading of the loan post-issuance. Because the transaction costs of renegotiation are low in this case, we can posit that the benefit to the borrower from a yank-a-bank provision would be low, while the costs to the lenders from ceding negotiating leverage to the borrower would be significant, as reflected in the following figures: 
Table 5: Case 4

\begin{tabular}{|c|c|c|c|c|}
\hline & $\begin{array}{c}\text { Gross } \\
\text { expected } \\
\text { payoff w/o } \\
\text { yank-a-bank } \\
\text { provision }\end{array}$ & $\begin{array}{c}\text { Gross } \\
\text { expected } \\
\text { payoff w/ } \\
\text { yank-a-bank } \\
\text { provision } \\
\text { payoff from } \\
\text { adding term } \\
\text { to credit } \\
\text { agreement }\end{array}$ & $\begin{array}{c}\text { Change in } \\
\text { range at } \\
\text { which } \\
\text { parties } \\
\text { should agree } \\
\text { to add term } \\
\text { to credit } \\
\text { agreement }\end{array}$ \\
\hline Borrower & $\$ 10 \mathrm{M}$ & $\$ 10.5 \mathrm{M}$ & $+\$ 0.5 \mathrm{M}$ & None \\
\hline Lenders & $\$ 10 \mathrm{M}$ & $\$ 7 \mathrm{M}$ & $-\$ 3 \mathrm{M}$ & \\
\hline
\end{tabular}

In this case, there is no price at which both parties are made better off by including the provision in the credit agreement; they should not agree to include the term. An informed law firm acting faithfully on behalf of its client would not introduce the term into the negotiation. If the firm wishes to increase its legal fees at its client's expense, however, it might try to convince the parties to spend time bargaining over the term, making both parties worse off. In that case, the firm will have used its information advantage in such a way that not only reduced the joint surplus from the transaction but also made its own client worse off.

To conclude Part IV, leveraged-loan financings represent one of several transaction types for which repeat-player law firms can extract significant rents by aggregating and deploying private information about market transaction terms. This opportunity exists because (1) such financings involve complex, heavily negotiated terms that are generally private; (2) multistage negotiations leave room for the exercise of bargaining power; and (3) pricing their terms would be exceptionally difficult for one-off players. Yet a law firm's experience with market terms is no guarantee that it will add value to the transaction; plausible scenarios exist for value-increasing, value-shifting, and value-decreasing behavior, as elaborated further in Part V below.

\section{IS THIS REALLY VALUE? SOME CLARIFICATIONS AND IMPLICATIONS}

Notwithstanding its favorable description of the role played by repeat-player law firms, this Article has provided no assurance thus far that law firms' market knowledge will on average create value in corporate transactions. It has merely described in general terms why such market knowledge may create value and why clients appear willing to pay for it. Part IV addresses the value-proposition of law firms' market knowledge more rigorously. We cannot conclude a priori that transactional lawyers create a positive-sum game for the parties. Instead, transactional lawyers' contribution may, for any given transaction, fall into one of three possible categories: (1) value-adding (i.e., increasing the 
joint transaction surplus, net of legal fees); ${ }^{98}$ (2) value-shifting (i.e., making their client better off, but solely at the expense of the transaction counterparty, thereby reducing joint transaction surplus once legal fees are taken into account); or (3) value-decreasing (defined here as both reducing joint transaction surplus and making their own client worse off). This Part discusses the conditions in which lawyers' market-information function falls into each of these three categories. ${ }^{99}$

\section{A. Value-Adding vs. Value-Shifting}

Law firms can use their market information to shift value, rather than to increase it. Because they are negotiated in stages, with the price terms fixed upfront, ${ }^{100}$ many corporate transactions leave significant room for value-shifting behavior. The extent of value-shifting behavior will be determined largely by the parties' relative bargaining power. Yet the parties' relative information also plays a role. Recall that law firms' market knowledge is potentially valuable because complex corporate transactions are characterized by incomplete and asymmetric information. ${ }^{101}$ Where new deal terms are constantly arising, where market forces rapidly affect the relative prices of all deal terms, and where information about such terms and their market prices is rarely public, the counterparties are likely to hold inaccurate and divergent beliefs about the market price of each term. They may even be unaware of the existence of certain deal terms that would increase their surplus from the transaction. Negotiations over transactional terms, then, represent a particular instance of bilateral bargaining with incomplete information. ${ }^{102}$ When the counterparties value transaction terms differently and are not aware of each others' valuations, their negotiated agreement should create less joint surplus than under perfect information. ${ }^{103}$ To the extent that transactional lawyers provide one party with better information about deal terms and their current pricing, they may either increase the size of the joint transaction surplus, making both parties better off, or simply increase their client's share of the transaction surplus, making that party better off at the other party's expense.

A firm's knowledge of market terms is more likely to be value-adding when it decreases the parties' information asymmetry because symmetrically informed parties should price terms close to their market values. Equivalently, whether a law firm's intervention increases aggregate transaction value or merely shifts value in favor of one party may depend on the original direction and degree of the information asymmetry

98. See Gilson, supra note 24 , at 243 (defining value-increasing behavior by transactional lawyers).

99. The other functions plausibly served by transactional lawyers-including transaction-cost engineering, gatekeeping, and regulatory expertise-are ignored for this purpose.

100. See supra Section III.A.2 (discussing multi-stage negotiations in which the price terms are set first).

101. See Gilson, supra note 24 , at 253 (noting that information about capital assets is "one of the most expensive and poorly distributed commodities"); id. at 251 (recalling that business lawyers cannot add value in a world in which the perfect-market assumptions are satisfied).

102. See, e.g., Kalyan Chatterjee \& William Samuelson, Bargaining Under Incomplete Information, 31 OPERATIONS RES. 835, 837-39 (1983) (providing a model of bilateral bargaining under incomplete information).

103. See id. at 836 (stating that "[b]argaining under uncertainty will, in general, fail to be Pareto efficient"); William Samuelson, Bargaining Under Asymmetric Information, 52 ECONOMETRICA 995, 1004 (1984) (concluding that the parties in a bilateral monopoly bargaining game may fail to reach mutually beneficial agreements when information is asymmetrically distributed). 
between the parties. Assume that Party A is significantly more informed than Party B with respect to the scope and pricing of deal terms. If Party $B$ hires an experienced law firm that mitigates its informational disadvantage, we should expect more efficient bargaining and an increase in the overall transaction value to result. If, on the other hand, Party $A$ hires an experienced law firm that further increases its informational advantage relative to Party $B$, the informational asymmetry between the parties will be exacerbated, potentially allowing more transaction value to be shifted toward Party A at Party B's expense.

The implications are, admittedly, both intuitive and predictable. When a company that rarely engages in large transactions is negotiating opposite a major investment bank, for example, it would do well to seek a high-volume law firm as its counsel. On the other hand, an investment bank armed with a high-volume law firm can, if the other side is poorly represented, capture much of the transaction surplus for itself by exploiting and exacerbating the other side's informational disadvantage. The investment bank will come out ahead, net of legal fees, even if the overall transaction value has been reduced by their counsel's intervention in the transaction.

\section{B. Value Decreasing}

When a law firm engages in value-shifting, it is still acting as a faithful agent to its client: it seeks to maximize its client's surplus, even if doing so results in less aggregate surplus to be shared between the parties. Yet a firm might also be incentivized to use market information at the expense of its own client. If so, law firms with market information can conceivably make both parties worse off. Recall, for example, that new terms are constantly being introduced in the market for certain types of transactions. There is no predetermined scope of bargaining or fixed number of terms to be negotiated, and the set of terms ultimately negotiated by the parties will be largely determined by their counsel. For a given transaction, imagine that the lawyers continue indefinitely to add items to the list of terms to be negotiated, subject to the sole constraint that they be at least marginally related to the subject matter. At a certain inflection point, the cost of negotiating all of these terms (including legal fees, the client's time, the costs of interpreting or amending the agreement ex post, etc.) will exceed the benefits (the increase in transaction surplus from the additional terms), and the client's expected payoff will begin to decline, as illustrated by the curve in Figure 1a.

While a firm with market knowledge should, by definition, have a good sense of where the inflection point lies, the less-informed client may not. Unfortunately, the firm's private incentives may cause it to continue beyond that point: the lure of increased billable hours can lead to excessively lengthy negotiations and overly complex agreements. While firms' reputational concerns should limit this type of agency cost, they are unlikely to eliminate it. ${ }^{104}$ Beyond a certain point, the practice of acquiring, maintaining, and utilizing market knowledge of deal terms amounts to a lawyer-created solution to a lawyer-created problem.

104. See Coates, supra note 19 , at 1310 ("[L]awyers determine key terms in the 'corporate contract,' due to agency costs between owner-managers and their lawyers."). 
Figure 1a: Relationship Between Payoff to Client and Number of Negotiated Deal Terms for a Given Transaction Type.

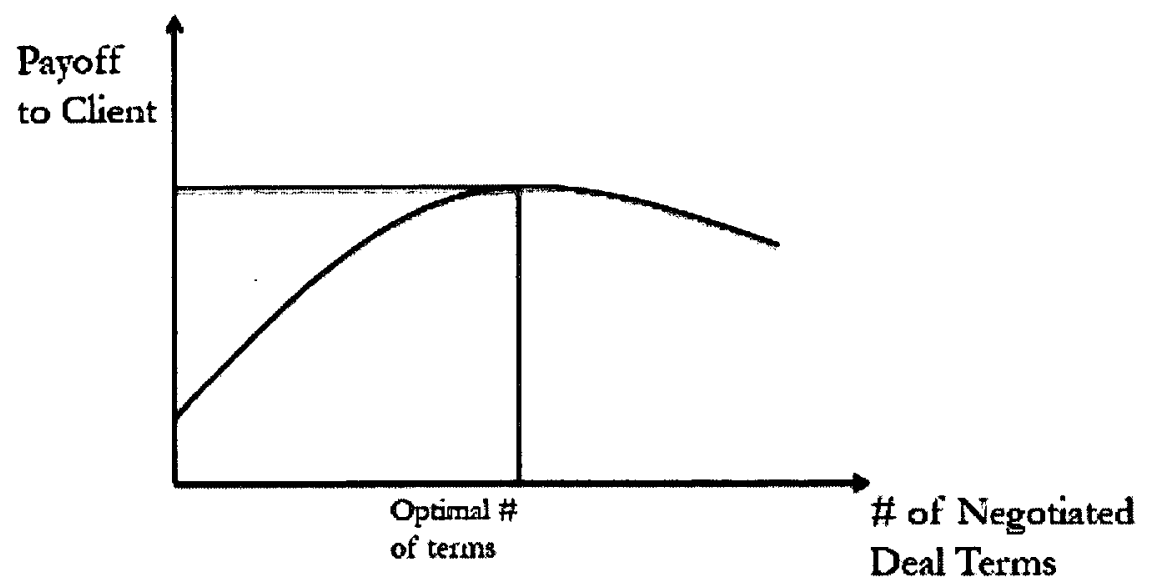

The mere fact that the number of deal terms has been increasing for certain transactions should not alone be viewed as evidence of greater agency costs, however. As argued above, the cost of compiling and using market knowledge has declined in recent decades due to technological advances and larger law firms. Thus, the point at which the client's payoff begins to decline from negotiating an additional term has almost certainly shifted outward for such transactions (as illustrated by the dotted curve in Figure 1b), thus justifying a larger number of negotiated deal terms.

Figure 1b: Relationship Between Payoff to Client and Number of Negotiated Deal Terms for a Given Transaction Type-Effect of Decline in Cost of Acquiring Market Information.

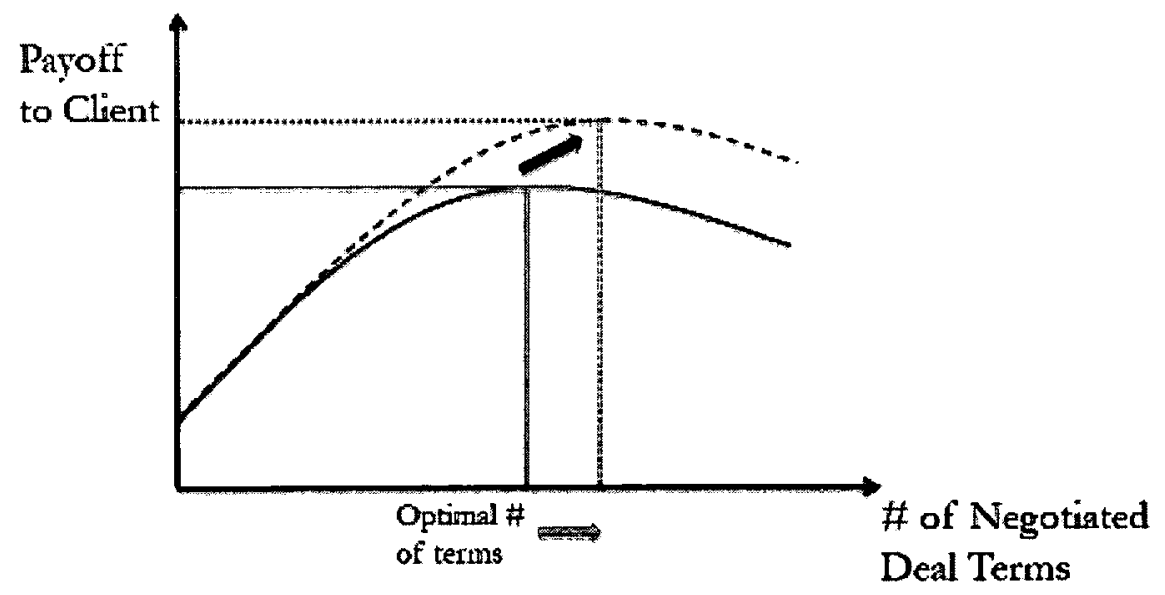




\section{Conditions Under Which Market Knowledge Should Provide Value to Clients}

We can now delineate more precisely the conditions under which market information will indeed be value-increasing in a transactional context. First, for a firm's market knowledge to provide any benefit to its clients, the transaction's terms cannot be entirely standardized (that is, non-negotiable) and uniformly priced in a competitive market. In other words, the relevant transaction agreement cannot be a commodity. ${ }^{105}$ While much of the finance literature treats corporate transactions--and, implicitly, transactional agreements - as commodities, for many transaction types this is far from the case. In particular, bilateral transactions in which the terms are heavily negotiated and tailored to the particular parties should, as discussed above, involve disparate pricing and allow for bargaining power to affect non-price terms. ${ }^{106}$

Second, market information must be scarce in order to be valuable. As aggregators of market information, law firms can extract greater rents when their market knowledge is costly to obtain. We therefore look for transactions with terms that are private or that change so rapidly that their publicity alone is not sufficient for clients to price them accurately. Similarly, law firms' use of market knowledge is more likely to be valueincreasing if there is no alternative source of market information. The recent emergence of service providers that aggregate transactional deal terms is a development to be applauded, yet as discussed above, they are unlikely to match law firms' access to private deal terms.

Third, a transaction involving significant asymmetry in the parties' knowledge of deal terms should generate the greatest benefits from a law firm's market knowledge, so long as the firm represents the lesser-informed party. This suggests that unsophisticated parties can benefit the most from law firms' market knowledge, particularly when they are facing a transaction counterparty that is itself a repeat player, such as an investment bank or large private equity firm. Yet the prediction that unsophisticated parties would be more likely to hire firms with market information does not seem to be borne out in practice: the most sophisticated clients tend to hire repeat-player law firms for transactions. ${ }^{107}$ This may simply reflect another information problem. Unsophisticated clients may not adequately appreciate their bargaining disadvantage or correctly identify firms that can remedy it. Sophisticated parties should be well aware of the advantage of market knowledge and therefore, surprisingly, be most likely to make use of elite counsel.

Fourth, large transactions benefit more from law firms' market knowledge than do small ones, all else being equal. With large transactions (as measured by the overall deal

105. Richard Susskind has established a classification for the degree to which contracts can be commoditized. See SUSSKIND, supra note 1, at 28-33. Susskind argues that, over time, any given contract type will tend to move along the path from fully bespoke (meaning that the contract is drafted entirely from scratch) to fully commoditized, with intermediate steps in which the contract is standardized, systematized, and packaged. Currently, agreements such as highly-leveraged financing and mergers and acquisitions are far from commoditization. We need not speculate if and when that will change, but we can safely predict that there will always be some subset of transactional contracts that are highly complex, highly negotiated, and rapidly changing, even though that subset may change over time. For such transactions, so long as the terms remain largely private, high-volume law firms will have a major advantage and rent-seeking opportunity if they are able to aggregate and make use of their market knowledge.

106. See supra note 67 (discussing the literature on bargaining power in corporate transactions).

107. See Davidoff, supra note 83 , at 535-37 (demonstrating that the largest private equity firms tend to engage the same small group of elite, repeat-player law firms for their acquisition and financing transactions). 
price), the cost of engaging a high-volume law firm is more likely to be offset by the additional benefit from obtaining better economic terms. The latter explains why the most elite firms are so profitable: they specialize in market information with respect to the very largest corporate transactions.

Finally, law firms with market information are more likely to create value when the agency costs in their relationships with clients are low. They are more likely to use their market knowledge to increase clients' share of transaction surplus, rather than to prolong negotiations beyond the value-maximizing point, if there is some check on their ability to exploit clients in this fashion. Such checks might include the client being a repeat player for the transaction at issue (resulting in less informational asymmetry between firm and client), the client having an experienced general counsel or other senior in-house lawyers with a transactional background (resulting in better monitoring of the firm), or the law firm having an established (and therefore valuable) reputation for providing faithful service to clients.

To summarize, law firms' market knowledge will be the most valuable for large, bilaterally-negotiated, complex, private transactions. The law firms that are able to compile and gain expertise in market information about transaction terms tend to be large, repeat players for such types of transactions. Thus, contrary to the prevailing predictions for Big Law as a whole, the small subset of law firms that meet these requirements should continue to charge high fees, grow larger, resist commoditized legal work, perform work that inhouse counsel cannot, and attract business even from clients with which they have no ongoing relationship.

\section{Do Law Firms Really "Price" Transaction Terms?}

Firms' knowledge of management practices with respect to market information vary considerably, yet we can make certain generalizations about how they compile it and how they use it. The starting-point for law firms' market knowledge is, as discussed, a large volume of the final transaction documents for a particular transaction type. Through their representation of several different clients, high-volume law firms naturally build up such a supply. The terms of these transactions can then be compared across deals, as in tables (grids) presenting similar transactions side-by-side and covering each of their material terms. ${ }^{108}$ With the further addition of database software, lawyers can search for a specific deal term to determine whether it was included in recent transactions and in what specific form. So long as clients' documents are internally accessible to all lawyers in a given practice group, regardless of which lawyers actually drafted them, every lawyer has access to the firm's market information. The degree of sophistication of knowledge-management practices is firm-dependent, but in all cases the benefit of each additional transaction inures to the entire firm.

Once market information has been compiled, stored, and made accessible, firms must decide how to make use of it. Preparing comparison tables of terms and simply sharing

108. What's Market, PRAC. L., http://us.practicallaw.com/resources/us-whats-market (last visited Nov. 8, 2015). For an example of what such a table might look like, select the "Compare" option for selected deals. Note, however, that this database includes only publicly available transaction documents, and the tables cover only a very small subset of the material terms in any given transaction. In practice, law firms' comparison tables would be significantly more detailed. 
them with a client may, on its own, afford the client a bargaining advantage, if the client is sufficiently sophisticated to interpret the information and use it to devise its bargaining position. ${ }^{109}$ In most cases, however, the firm's market information will instead serve to instruct the lawyers themselves as to current market conditions. They can then in turn instruct clients as to what to ask for in negotiating terms (at the term sheet stage, for example, where the business teams take the lead) or use the information themselves during negotiations (in the later stages that are dominated by lawyers).

The question, of course, is how exactly lawyers translate market information into specific moves in a transaction negotiation. As discussed, market information is valuable in that it (1) informs clients of new terms, and (2) helps them "price" terms, which is shorthand for estimating the likely concessions that it can extract from the counterparty and the value of those terms to the client. Yet what does it mean to suggest that lawyers engage in pricing terms? That they would assign specific dollar values to each potential term in a negotiation is plainly implausible. Yet, in most cases, they can achieve effectively the same outcome by developing an intuitive understanding of the value of specific terms and combinations of terms. The latter is sufficient for them to become skilled at two forms of pricing: risk equalization and relative pricing.

First, we are not accustomed to thinking of lawyers as engaged in pricing, in part because lawyers more often speak in terms of risk than value. Lawyers have become highly adept at determining what combinations of terms will result in the same level of risk for their client under current market conditions. Take, for example, the negotiation of a large corporate loan. The borrower may request a provision granting it the right to sell a certain value of assets without requiring lender permission. Lender's counsel may then request additional collateral from the borrower, for example, with the goal of having the borrower present the same credit risk as before. There is thus little distinction between assessment of risk and estimation of value in practice.

Second, we also fail to recognize lawyers as engaged in pricing because they are undoubtedly better at relative pricing than at absolute pricing. It is easier for a transactional lawyer to advise a client that it could do "better" by negotiating with a different counterparty than it is to estimate precisely how much more surplus the client could obtain from negotiating with a different counterparty. Similarly, transactional lawyers are likely to be more accurate at ranking terms against one another ("Term A should be worth more to you than Term B") than at ascribing a specific value to each term ("Term A should be worth $x$ dollars to you").

Thus, to the extent that transactional lawyers price terms, they admittedly do so only informally, and likely on the basis of relative rankings of terms and options, rather than by assigning specific dollar values. As practiced by transactional lawyers, term pricing is, as the cliché goes, more art than science. ${ }^{110}$ The larger point is that nothing in this Article should be taken to suggest that lawyers can price terms perfectly accurately. Rather, the

109. Whether sharing information in this manner across clients is permissible under existing rules of professional conduct will depend on the precise details of the representation and the form and scope of the information provided. See infra Section V.F (discussing the value of confidentiality).

110. See, e.g., Edward A. Bernstein, Law \& Economics and the Structure of Value Adding Contracts: A Contract Lawyer's View of the Law \& Economics Literature, 74 OR. L. REV, 189, 217 (1995) (noting that "value maximizing contractual decisions require judgment rather than mere mathematical calculations" and describing such decisions as "more analogous to art than engineering"). 
claim is that clients should, on average, be expected to price terms more accurately when they engage law firms having access to market information than with uninformed counsel and should therefore obtain better outcomes.

\section{E. Gilson Revisited}

A final clarification is in order as to where the market-knowledge hypothesis fits into the existing literature on transactional lawyering. Given the breadth of Gilson's hypothesis in particular, we might ask whether firms' expertise in market information is merely a particular instance of transaction-cost engineering. As an initial matter, none of this Article's claims would be impaired by placing market knowledge under the broad umbrella of transaction-cost engineering. Further, as discussed below, there is likely to be considerable overlap between the two hypotheses at the stage where a lawyer actually applies the firm's market information to a particular client's transaction. Yet there are certain dimensions in which the two hypotheses part company.

First, while both hypotheses claim that transactional lawyers mitigate information problems between transaction counterparties, ${ }^{111}$ the categories of information at issue are distinct, and thus, the role played by transactional lawyers is different under each view. Gilson helpfully defines a corporate transaction as the transfer of a capital asset between parties. ${ }^{12}$ In acquisitions, the capital asset might consist of stock or corporate assets, for example. The transaction-cost-engineering hypothesis rests on information asymmetry between the parties concerning the value of the capital asset to be transferred in the transaction-in our example, the value of the target company's assets or stock. Lawyercrafted provisions such as representations and warranties, for example, enable the parties to minimize the transaction costs resulting from the fact that the selling party is more informed about the value of the target company than is the buyer. This Article identifies a different information set affecting transaction value, namely the range of terms that the parties should negotiate and their market pricing. Even assuming that the parties are equally or perfectly informed about the value of the asset to be transferred between them, they may nonetheless fail to maximize their joint surplus from the transaction: they may simply be unaware of certain value-increasing transaction terms that have recently appeared in the market, or they may fail to agree to known value-increasing terms because they have incorrectly priced them. Where lawyers can assist with market-term awareness and pricing, they can increase transaction value in a manner that is not strictly contemplated by the transaction-cost-engineering hypothesis.

Second, while using market information to help clients make more efficient bargains can surely be characterized as reducing transaction costs, Gilson appears to have a narrower conception of transaction-cost engineering in mind, based on his own proffered examples. In his case study of merger agreements, Gilson focuses on lawyer tasks such as crafting purchase-price adjustments and determining which representations and warranties the

111. Recall that the value of a law firm's market information depends on such information being scarce and, better still, asymmetrically distributed between the transactional counterparties. Gilson's transaction-costengineering hypothesis also rests on information asymmetry between transaction counterparties. See Gilson, supra note 24, at 269 (describing the goal of acquisition agreements as "[reducing] . . informational differences between the parties at the lowest possible cost").

112. See id. at 249 ("Characterizing transactions as the transfer of capital assets is important ...."). 
parties should make. ${ }^{113}$ At base, such provisions all serve the same function: efficiently allocating uncertainty about the value of the company between the parties. Such terms do not (or need not) depend directly on the terms obtained by other transaction counterparties in the market. In other words, transactional lawyers can conceivably engage in transactioncost-engineering - under Gilson's understanding of it-without having access to market information. Conversely, we could imagine lawyers using market information in transactions without directly engaging in transaction-cost engineering. If a firm's client is sufficiently sophisticated, for example, simply providing the client with a comparison of the private terms of recent transactions could, on its own, allow the client to reach a better bargain: it would amount to a pure sale of market information, divorced from the firm's expertise in working with such terms.

Where the two sources of law firm value diverge is perhaps best illustrated by the difference between (1) a senior partner with years of experience working on a particular type of transaction, but who is the only lawyer at her firm to work on such transactions, and (2) an associate at a high-volume firm who has access to his firm's database of all recent transaction terms, but who has negotiated few such transactions on his own. The first lawyer is a pastiche of a transaction-cost-engineer, while the second represents pure market information. ${ }^{114}$ Note, similarly, that the task of compiling market information is fairly passive and appears largely distinct from what Gilson envisions as transaction-cost engineering. When the task turns to applying a firm's market information to a particular transaction, however, there is likely to be considerably more overlap between the two hypotheses. Moving from the general (market information) to the specific (applying market information to a particular client and transaction) undoubtedly requires experience beyond simply observing other parties' transaction terms, and this begins to look more like Gilson's transaction-cost engineering. In practice, of course, the two types of knowledge need not be-and generally are not-mutually exclusive.

\section{F. The "Value" of Confidentiality}

If clients engage elite law firms at least in part for their market knowledge, this has profound implications for the rules and practices relating to the confidentiality of client information. The premise that clients value confidential legal services is traditionally left unchallenged, and the rules of professional conduct for attorneys are drafted accordingly. ${ }^{115}$ Yet if clients expect to obtain a better transactional bargain through a firm's market knowledge, they will happily pay the firm for the use of its other clients' information, whether implicitly or explicitly. In doing so, rational clients should anticipate that the firm will, in turn, use their own information for the benefit of other clients. If the benefit of access to market knowledge is expected to exceed the benefit, if any, from keeping their own transaction terms confidential, clients will be willing participants in a

113. See id. at 257-62 (discussing the merger agreement process).

114. It should go without saying that the client would be better off with both types of expertise.

115. See MODEL RULES OF PROF'L CONDUCT r. 1.6(a) (ABA CTR, FOR PROF'L RESP. 2015) ("A lawyer shall not reveal information relating to the representation of a client unless the client gives informed consent, the disclosure is impliedly authorized in order to carry out the representation or the disclosure is permitted by paragraph (b)."); MODEL RULES OF PROF'L CONDUCT r. 1.9(c)(2) (ABA CTR. FOR PROF'L RESP. 2015) (imposing a similar duty of confidentiality with respect to former clients). 
market for transactional terms.

We should not be surprised, then, that a company contemplating a major transaction would choose to engage a top-tier law firm even where the company has had no prior dealings with the firm and where the firm has completed similar transactions for many of the company's direct competitors. In fact, the law firm's knowledge of competitors' deal terms only increases that firm's value to the company. The prediction that competitors will seek the same law firm(s) for their transactions stands in direct contrast to the paradigm of relationship lawyering, under which a company seeks to monopolize the services of a single law firm, in part to prevent company information from seeping to competitors. ${ }^{116}$ Large corporations, investment funds, and financial institutions are well aware that elite firms also work for their direct competitors. Under the market-knowledge hypothesis, clients hire such firms not despite this but because of this.

It may thus be past time to revise the rules of professional conduct so as to explicitly accommodate transactional clients' interests in sharing information. Currently, the rules' application to this context is largely unclear. ${ }^{117} \mathrm{~A}$ conservative interpretation would require law firms to obtain individual client waivers before referring to any of such clients' transaction terms in negotiations on behalf of another client. Such a default prohibition on information-sharing creates a free-rider problem, in which each client seeks to keep its own information confidential by refusing to sign a waiver, yet still intends to benefit from the firm's knowledge of other clients' information. At equilibrium no client will choose to waive the confidentiality of its information, resulting in no information-sharing across clients. Yet this outcome is not in clients' collective interest: as discussed, there is a positive externality to firms' market information.

This leaves it to law firms to test the rules' boundaries under conditions of significant uncertainty. As a result, firms' individual practices as to the use of clients' transaction terms likely vary considerably, yet are unlikely to be fully disclosed to clients. In the absence of a waiver, it is impossible to say whether clients have implicitly acquiesced to the use of their information, or, more troublingly, are simply unaware of their firms' practices. Recognizing the value of market-information sharing for clients in the aggregate, the rules of professional conduct for lawyers could be revised in one of two ways. First, they could state explicitly what practices are and are not permissible with respect to clients' transaction terms. Alternatively, the current default rule of confidentiality could be reversed, by explicitly allowing firms to share certain transaction information across clients unless the client expressly opts out of such a regime. ${ }^{118}$ If clients are willing to sacrifice

116. See generally Gilson, supra note 13 (describing the paradigm of relationship lawyering).

117. In addition to the general duty to keep client information confidential, the rules of professional conduct also prohibit a law firm from using a client's information to that client's detriment. See MODEL RULES OF PROF'L CONDUCT r. 1.8(b) (ABA CTR. FOR PROF'L RESPON. 2015) ("A lawyer shall not use information relating to representation of a client to the disadvantage of the client unless the client gives informed consent ....'). What this general prohibition entails for firms representing various competitors or potential competitors in a transactional context is less than clear. See, e.g., Maritrans GP, Inc. v. Pepper, Hamilton \& Scheetz, 602 A.2d 1277,1282 ( $\mathrm{Pa} .1992$ ) (finding that a law firm's representation of a client whose interests were materially adverse to a former client represented in a substantially related matter constituted a breach of fiduciary duty). A law firm's use in negotiations of one client's deal terms, even without attribution, in order to obtain a better economic deal on another transaction for that client's competitor would, absent an express waiver, seem to fall within a sizable gray area of the law.

118. While there is still the possibility of free-riding under such an opt-out regime, the overall effect should 
confidentiality for the benefit of current market knowledge, the relevant rules and institutions should permit them to do so both efficiently and unambiguously.

\section{CONCLUSION}

Notwithstanding sluggish demand for law-firm services in the aggregate, elite law firms in the United States continue to thrive and to dominate the market for the largest corporate transactions. Existing accounts of the value provided by transactional lawyers do not fully explain this state-of-play, because they omit a crucial function performed by repeat-player law firms. Such firms aggregate private market information about deal terms and use this information to identify value-increasing terms for their clients and to assist with term pricing. Traditional accounts of financial contracting have failed to recognize the rapidly expanding set of transaction terms and the difficulty of pricing them, due to common misconceptions about the actual practice of transactional negotiations. To the extent that elite law firms can improve their clients' outcomes in major transactions by using market knowledge, they should remain largely immune from competition from inhouse counsel, the commoditization of legal work, and client pressure to decrease fees.

be greater information-sharing than under the current default rule if we accept the prediction from behavioral economics that setting the default rule affects the parties' choices. See generally Cass R. Sunstein, Switching the Default Rule, 77 N.Y.U. L. REV. 106 (2002) (critiquing the view of conventional economic analysis that changes to default rules should not have significant effects on behavior). 